Campbell University School of Law Scholarly Repository@ Campbell University School of Law

2018

Guns, Knives, and Swords: Policing a Heavily Armed Arizona

Shawn E. Fields

Follow this and additional works at: https://scholarship.law.campbell.edu/fac_sw 


\title{
Guns, KNIVES, AND Swords: Policing a Heavily Armed Arizona
}

\author{
Shawn E. Fields*
}

Arizona is widely recognized as the most permissive state in the country for public weapons possession. In 2010, then-Governor Jan Brewer famously removed all permitting requirements for public concealed carry of firearms, making Arizona only the third "constitutional carry" state in the nation. Also in 2010, and to much less fanfare, Arizona became the first state to prohibit local governments from enacting any regulations restricting the sale or possession of knives of any kind, including swords, maces, and other exotic blades. Today, Arizona remains the only state in the country with virtually no restrictions on the public concealed carry of any type of bladed weapon. In part owing to this deregulatory environment, as many as six percent of all Arizonans report publicly carrying a concealed deadly weapon on their person or in their vehicle. ${ }^{1}$

But these laws have also created confusion for Arizona police officers charged with protecting the public. For over a century, Arizona officers could justifiably initiate an investigatory stop of a publicly armed individual based on little more than a reasonable suspicion that such possession was unlawful. But in a state where a significant percentage of the population lawfully possesses weapons in public, Arizona police must now discern which lethal weapons carriers are law abiding citizens and which ones pose true criminal threats to the public. Increasing the confusion for Arizona law enforcement, the Ninth Circuit and Arizona Supreme Court have recently authored conflicting opinions regarding whether a lawfully stopped individual can be frisked solely because he is armed or whether he must also give the officer reasonable suspicion that he is "presently dangerous."

This Article examines three distinct aspects of Arizona law and policy as it relates to this growing confusion. First, it challenges the efficacy and constitutionality of Arizona's "duty to inform" law, which seeks to clarify this reasonable suspicion quandary by requiring concealed weapons

\footnotetext{
* Assistant Professor of Law, Campbell University Norman Adrian Wiggins School of Law; Criminal Appellate Advocate, Judicial Council of California; former Board Member, Community Review Board on Police Practices in San Diego; J.D. 2007, Boston University School of Law; B.A. 2003 in Political Science, Yale University.

1. Concealed Carry Statistics, Guns to CARRY, https://www.gunstocarry.com/concealedcarry-statistics/\#info [https://perma.cc/W3K5-J7ZK] (last visited May 25, 2019).
} 
possessors to affirmatively disclose the presence of weapons to police officers when asked. As a matter of federal constitutional law, officers can only require citizens to cooperate with inquiries if reasonable suspicion already existed to justify the stop. In contrast, by requiring citizens to voluntarily disclose information to officers, "duty to inform" laws arguably place these encounters with law enforcement outside the traditional Terry v. Ohio stop context, thus rendering the encounter consensual and failing to solve the reasonable suspicion issue.

Second, the Article considers the competing case law in Arizona regarding the "armed and dangerous" prong of stop and frisk for law ful gun carriers. The Arizona Supreme Court in State v. Serna held that lawful weapons carriers cannot automatically be considered dangerous for purposes of a protective frisk. The Ninth Circuit, in United States v. Orman, held otherwise, and focused on characteristics of gun ownership not explicitly considered by the Arizona Supreme Court. But both cases involved consensual encounters and not involuntary investigative stops. The Article surveys case law from other jurisdictions to offer a balanced approach to frisks of lawfully stopped, lawfully armed Arizonans.

Third, the Article highlights policy considerations relevant to resolving these competing perspectives, as well as the competing interests of Arizonans in exercising their statutory possession rights and of officers in protecting themselves and others when faced with a public weapon carrier. In doing so, the Article explores for the first time in scholarly literature what, if any, parallels can be drawn from the experience of officers stopping and frisking lawful gun carriers and officers stopping and frisking lawful knife carriers.

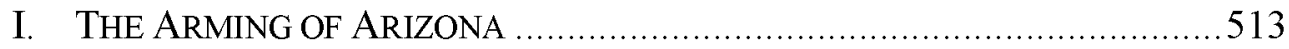

A. The National Evolution of Concealed Carry Legislation................515

B. Arizona: From Gun Control to "Constitutional Carry" .................518

C. Heller and McDonald in Arizona................................................523

D. The Unique Case of Arizona's "Blade" Laws .............................525

II. "Reasonable Suspicion" and Policing a Heavily ARMEd

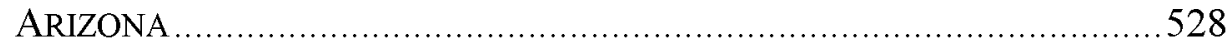

A. The Stop and Frisk Paradigm ................................................529

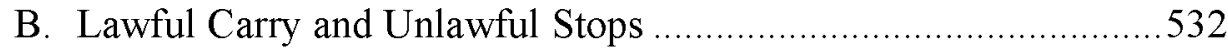

C. Arizona's "Duty to Inform" Law ................................................534

III. DOES ARMED EQUAL DANGEROUS IN ARIZONA? ..............................537 

A. Ninth Circuit: United States v. Orman
538
B. Arizona State Courts: State v. Serna ... 540
C. What About Nonconsensual Encounters? 544
D. Policy Considerations for Guns and Knives 546

CONCLUSION 550 


\section{INTRODUCTION}

On August 8, 2015, the Arizona newspaper Arizona Republic ran a story with the following headline: Celebration or Concern? We 're No. 1 for Guns. ${ }^{2}$ The story reported that, "[f]or the third straight year, Arizona was ranked [the] best state in the nation for gun owners by Guns \& Ammo magazine, which praised the state's self-defense and carry laws, its shooting sports and strong gun culture." 3 The balance of the article considered the well-worn debate between gun rights advocates and gun control advocates reflected in the story's title: was this ranking to be hailed as a victory for the Second Amendment and responsible gun ownership, or denounced as the reason why "Arizona is the best state for criminals to get access to guns"? ${ }^{4}$

Two things remain unchanged in 2019. First, this aspect of the gun debate remains as intractable as ever. ${ }^{5}$ Second, Arizona remains among the most friendly states in the nation for firearms. ${ }^{6}$ In 2018, Guns \& Ammo ranked Arizona the best state in the nation for firearms for the fifth straight year, owing largely to its uniquely permissive concealed carry gun laws. ${ }^{7}$ The state allows Arizonans to carry concealed firearms in public, without a permit, in more places and with higher capacity magazines than anywhere else in the

2. Nihal Krishan, Celebration or Concern? We're No. 1 for Guns, ARIz. RePUBLIC, Aug. 8,2015 , at F1. The story appeared online a day earlier. Nihal Krishan, Celebration or Concern? Arizona Is No. 1 for Guns, AZCENTRAL.COM (Aug. 7, 2015), https://www.azcentral.com/story/news/local/arizona/2015/08/07/arizona-best-state-gunowners/31312751/ [https://perma.cc/229B-D2XE].

3. $I d$.

4. Id.

5. See Peter Baker \& Michael D. Shear, Another Shooting, Another Gun Debate. Will the Outcome Be the Same?, N.Y. TIMES (Feb. 22, 2018), https://www.nytimes.com/2018/02/22/us/politics/school-shooting-gun-debate.html

[https://perma.cc/R4R7-BLHE] (summarizing the state of the gun control debate after the Parkland, Florida high school shooting, including the response to the National Rifle Association lobbying efforts by "[t] he gun control side . . . a well-financed infrastructure that did not exist" before the twenty-first century); Elana Schor, The Gun Debate in Congress: From ConcealedCarry to the Assault Weapons Ban, Politico (Feb. 22, 2018, 5:42 PM), https://www.politico.com/interactives/2018/gun-control-debate-concealed-carry-to-assaultweapons-ban/ [https://perma.cc/PQZ6-UDCR] ("The fight over gun control is moving quickly.").

6. See Keith Wood, Best States for Gun Owners (2018), Guns \& AMMO (Oct. 31, 2018), $\mathrm{http}: / / \mathrm{www}$.gunsandammo.com/editorial/best-states-for-gun-owners-2018/327233

[https://perma.cc/AN2B-SXYD] (ranking Arizona first in the nation for guns in an environment where, "for the past six years . . . most states moved steadily in a pro-gun direction").

7. Id. ("An effort to weaken Arizona's firearm law preemption statute was defeated this session, keeping the state at the number one position in our survey for the fifth straight year."). 
nation. ${ }^{8}$ And a greater percentage of Arizonans carry concealed weapons on their person in public than virtually any other state. ${ }^{9}$

This Article does not wade into the overarching debate about whether these facts give cause for celebration or concern. Instead, it explores a littlediscussed byproduct of Arizona's concealed carry laws: the increasing difficulties faced by Arizona law enforcement in protecting such a heavily armed populace. In particular, the Article considers what constitutes "reasonable suspicion" of criminal activity to initiate an investigatory stop and protective frisk under Terry v. Ohio ${ }^{10}$ in a state where virtually anyone can lawfully carry a firearm anywhere in public. " While in a "constitutional carry" ${ }^{2}$ state like Arizona, officers can no longer rely on weapons possession

8. See Ariz. Rev. StAT. ANn. § 13-3102 (2019) (lifting concealed carry weapons ban and eliminating concealed carry permitting requirement); S. 1108, 49th Leg., 2d Reg. Sess. (Ariz. 2010); S. 1113, 49th Leg., 1st Reg. Sess. (Ariz. 2009) (entitling people in Arizona to carry concealed firearms in bars or restaurants); S. 1168, 49th Leg., 2d Reg. Sess. (Ariz. 2010) (banning property owners from prohibiting the storage of firearms in locked vehicles parked on their lot); Arizona, Giffords L. CTR. TO PREVENT Gun ViolenCE, https:/lawcenter.giffords.org/gunlaws/state-law/arizona/ [https://perma.cc/QJ85-LB59] (last visited May 25, 2019) (summarizing Arizona gun laws: "Arizona does not . . . [p]rohibit the transfer or possession of . . . large capacity ammunition magazines"); Arizona's Magazine Capacity Restriction, GunLaws101.com, https://www.gunlaws101.com/state/law/arizona/magazine-capacity-restriction

[https://perma.cc/KUW7-HKUX] (last visited Mar. 17, 2019) ("There are no magazine capacity restrictions in Arizona.").

9. Concealed carry statistics are notoriously difficult to compile, especially in a "constitutional carry" state like Arizona that does not require a state-issued permit to carry. However, one gun rights database tabulating CCW permits by state lists Arizona as having the fifteenth highest number of CCWs in the country, at 325,421. See Concealed Carry Statistics, supra note 1 . Of the fourteen states with greater absolute numbers of CCWs, only six of them (Alabama, Colorado, Indiana, Massachusetts, Utah, and Tennessee) have smaller populations than Arizona. See US States-Ranked by Population 2019, World PoPULATION REviEw, $\mathrm{http} / / /$ worldpopulationreview.com/states/ [https://perma.cc/P7KQ-J56P] (last visited May 25, 2019). But unlike Arizona, none of these six states have fully unrestricted "constitutional carry" laws allowing allow for full permit-less concealed carry. Craig Martin, Constitutional Carry State-by State, CONCEALEDCARRY.COM (Apr. 28, 2017), https://www.concealedcarry.com/reciprocity/constitutional-carry-state-by-state/

[https://perma.cc/6EQP-HNSE]. Thus, one can safely maintain that Arizona has at least among the highest percentage of concealed carry citizens in the country.

10. 392 U.S. 1 (1968).

11. See ARIZ. Rev. StAT. ANN. § 13-3102 (2019) (removing concealed carry permitting requirements in Arizona). Arizonans still remain subject to federal firearms laws, which prohibit possession of firearms by, among others, felons, 18 U.S.C. $\$ 921$ (a)(20) (2018), undocumented immigrants, domestic violence misdemeanants, unlawful users of or addicts to a controlled substance, dishonorably discharged veterans, and persons who have renounced their United States citizenship. 18 U.S.C. $\$ 922$ (b)(1) (2018).

12. James Bishop, Hidden or on the Hip: The Right(s) to Carry After Heller, 97 CoRNELL L. REV. 907, 911 (2012) ("Arizona ... allow[s] any legal resident to carry a concealed handgun without a permit; these are sometimes called "constitutional carry' jurisdictions."). 
alone as indicative of criminal activity sufficient to justify a stop, they still have a duty to protect innocent citizens from armed criminals. The fact that Arizona's "gun laws ... make it easy for criminals to get their hands on guns" only complicates this duty. ${ }^{13}$

Under Terry and its progeny, a police officer may "seize a person and subject him to a limited search for weapons" if the officer has reasonable suspicion that criminal activity is afoot. ${ }^{14}$ This "stop and frisk" standard contemplates a two-pronged analysis: an officer may (1) seize an individual for a brief investigatory stop upon "reasonable suspicion that the suspect was involved in, or is about to be involved in, criminal activity," and (2) frisk the outer clothing of the individual for weapons if she has "reason to believe that [s] he is dealing with an armed and dangerous individual." 15

This "reasonable suspicion" standard is "considerably less than proof . . by a preponderance of the evidence, and obviously less than is necessary for probable cause." 16 Arizona courts have reaffirmed repeatedly not only the low threshold for reasonable suspicion, ${ }^{17}$ but also the great deference afforded to officers in making this determination. ${ }^{18}$

But Arizona's public carry laws, enacted in 2010, present a direct challenge to the once widely held "assumption that a person carrying a concealed weapon was engaged in the crime of unlawful weapons possession," thus justifying a stop under the first Terry prong. ${ }^{19}$ Moreover, the once "nearly unanimous agreement that to be armed was to be dangerous," giving officers the right to frisk armed individuals under Terry's second prong, seems outdated in a state where the government's clear intent is to allow its citizens to lawfully and peacefully carry concealed weapons. ${ }^{20}$

13. Krishan, supra note 2; see also About the State Scorecard, BRADY CAMPAIGN, $\mathrm{http}: / / \mathrm{www}$.crimadvisor.com/?page=scorecard [https://perma.cc/4GSZ-CVCH] (last visited Mar. 17, 2019) (ranking Arizona as the state "with the loosest gun laws in the nation making [it] the best location[] for criminals and other dangerous people to easily get guns").

14. Terry v. Ohio, 392 U.S. 1,15 (1968).

15. Id. at 27; accord United States v. Bivens, 204 Fed. App'x. 835, 836 (11th Cir. 2006).

16. Navarette v. California, 572 U.S. 393, 396-97 (2014); United States v. Arvizu, 534 U.S. 266, 277 (2002) ("Reasonable suspicion . . . need not rule out the possibility of innocent conduct."); see also State v. Rogers, 924 P.2d 1027, 1031 (Ariz. 1996).

17. See, e.g., Rogers, 924 P.2d at 1030.

18. See, e.g., State v. Adair, 383 P.3d 1132, 1137 (2016).

19. Matthew J. Wilkins, Note, Armed and Not Dangerous? A Mistaken Treatment of Firearms in Terry Analyses, 95 Tex. L. REV. 1165, 1169 (2017); see also Jeffrey Bellin, The Right to Remain Armed, 93 WASH. U. L. REV. 1, 25 (2015) ("Traditionally, courts (and police) assumed that officers could stop and question someone they observed with a concealed handgun, at least in jurisdictions with strict regulation of concealed weapon carrying.").

20. Wilkins, supra note 19, at 1170. 
Within that context, this Article explores three distinct aspects of Arizona law and policy complicating this growing tension between increasingly permissive "right to carry" laws in Arizona and the obligation of officers to safely conduct investigative stops and searches.

First, Section I of the Article examines not only Arizona's permissive concealed carry firearms laws but also its uniquely permissive knife laws. In 2010 , Arizona became the first state in the country to broadly legalize the open and concealed public carry of any knife or "blade" regardless of size, function, or lethality. ${ }^{21}$ It concurrently became the first state in the nation to prohibit local municipalities from restricting or otherwise regulating the sale, possession, or transfer of blades. ${ }^{22}$ These all-encompassing permissive concealed weapons possession laws have directly contributed to the public "arming of Arizona."

Second, Section II of the Article considers the fact that weapons possession alone in Arizona can no longer give rise to reasonable suspicion of criminal activity under the Fourth Amendment, and Arizona's attempt to nonetheless authorize law enforcement to investigate armed citizens. In particular, it questions the constitutionality and efficacy of Arizona's socalled "duty to inform" law, which requires concealed carry permit holders to affirmatively disclose their status to police officers when approached and provide their permit and identification at an officer's request. ${ }^{23}$ As a matter of federal constitutional law, officers can only require citizens to cooperate with inquiries if reasonable suspicion already existed to justify the stop. ${ }^{24} \mathrm{In}$ contrast, by requiring citizens to voluntarily disclose information to officers, "duty to inform" laws arguably place these encounters with law enforcement outside the Terry stop context, thus failing to solve the reasonable suspicion issue. ${ }^{25}$

Third, the Article considers the impact of competing decisions in Arizona and the Ninth Circuit concerning whether an armed individual in public is per se dangerous and thus subject to a frisk under Terry's second prong. In State v. Serna, the Arizona Supreme Court held that, "[i]n a state such as Arizona

21. ARIZ. Rev. Stat. AnN. \$ 13-3120 (2019); Arizona Knife Laws, AM. KNIFE \& ToOL INST., https://www.akti.org/state-knife-laws/arizona/ [https://perma.cc/3756-L3YC] (last visited Mar. 17, 2019).

22. About Statewide Knife Preemption, AM. KNIFE \& ToOL Inst., https://www.akti.org/legislation/about-knife-preemption/ [https://perma.cc/AAH4-6EB7] (last visited Mar. 17, 2019) (listing ten states with knife preemption laws and date law was enacted, with Arizona enacting its law first in 2010).

23. See Ariz. Rev. Stat. AnN. § 13-3112 (2019).

24. See infra Section II.A.

25. See infra Section II.C. 
that freely permits citizens to carry weapons, both visible and concealed, the mere presence of a gun cannot provide reasonable and articulable suspicion that the gun carrier is presently dangerous." ${ }^{26}$ In contrast, the Ninth Circuit in United States v. Orman upheld the search of an Arizona man based solely on his possession of a concealed weapon. ${ }^{27}$ Adding to the confusion for Arizona law enforcement, both Serna and Orman involved consensual encounters with law enforcement, ${ }^{28}$ leaving open the question of whether and under what circumstances officers can frisk and disarm involuntarily stopped, armed Arizonans. Other jurisdictions considering the issue have failed to provide a principled or consistent solution, ${ }^{29}$ and the United States Supreme Court declined the opportunity to resolve a growing circuit split in late $2017 .{ }^{30}$

The Article concludes by articulating policy considerations pointing to a modified categorical approach to frisking armed Arizonans, wherein known firearms possessors are subject to an automatic protective frisk for officer safety, while possessors of knives or other weapons may be searched only where circumstances so require it. ${ }^{31}$ The Article draws upon the parallels of the firearms experience and borrows from tort law to advocate for a balanced risk-assessment approach to the seizure of knives during an investigatory stop in Arizona. This inherently flexible approach both reflects the spirit of the "reasonableness" approach embodied in Terry and the text of the Fourth Amendment, and offers a balance between the significant rights of armed Arizonans and the solemn obligations of the state's police officers.

26. State v. Serna, 331 P.3d 405, 410 (Ariz. 2014).

27. See United States v. Orman, 486 F.3d 1170, 1172, 1176 (9th Cir. 2007).

28. Serna, 331 P.3d at 411 ("Our holding governs only those circumstances in which the police wish to search a person with whom they are engaged in a consensual encounter."); Orman, 486 F.3d at 1177 ("We hold that Officer Ferragamo's initial encounter with Orman was consensual. ...").

29. See, e.g., United States v. Robinson, 846 F.3d 694, 705 (4th Cir. 2017) (Wynn, J., concurring) (concluding that "lawfully-stopped individuals armed with firearms are categorically dangerous" and thus lawfully subject to search); Northrup v. City of Toledo Police Dep't, 785 F.3d 1128, 1132 (6th Cir. 2015) ("Where it is lawful to possess a firearm, unlawful possession 'is not the default status.' There is no 'automatic firearm exception' to the Terry rule."); United States v. Ubiles, 224 F.3d 213, 218 (3d Cir. 2000) (comparing an officer's stop of an armed individual in a concealed carry state based on a suspicion that possession might have been illegal as to a stop of an individual because he "possessed a wallet, a perfectly legal act").

30. United States v. Robinson, 846 F.3d 694, 705 (4th Cir. 2017), cert. denied, 138 S. Ct. 379 (2017).

31. See Robinson, 846 F.3d at 703-04 (Wynn, J., concurring). 


\section{THE ARMING OF ARIZONA}

On April 16, 2010, Arizona transformed from one of the most restrictive public weapons carry states in the country to arguably the most permissive. When then-Governor Jan Brewer signed Senate Bill 1108 into law, repealing a century-old concealed carry weapons ban, ${ }^{32}$ Arizona became only the third state (after Alaska and Vermont) to allow the public concealed carry of a firearm without a permit. ${ }^{33}$ That same day, and to much less fanfare, Governor Brewer signed a first-in-the-nation "knife preemption" law, the effect of which was to strip local municipalities of the ability to regulate knives and other blades and to broadly legalize without restriction the public carry of any "cutting instrument." ${ }^{34}$

Not surprisingly, these permissive weapons laws have significantly aided the arming of Arizona. While firearms statistics are notoriously difficult to validate, ${ }^{35}$ particularly in states like Arizona that do not require firearms registration or the application for a concealed carry permit, numerous studies rank Arizona as one of the most heavily armed states in the country. ${ }^{36} \mathrm{~A}$ CBS News study found that nearly one in three Arizonans own a firearm, ${ }^{37}$ and a Pew Research Center study on gun ownership noted that approximately twothirds of all gun owners own more than one gun. ${ }^{38}$ Moreover, despite rescinding the need to maintain a concealed carry weapons $(\mathrm{CCW})$ permit,

32. S. 1108, 49th Leg., 2d Reg. Sess. (Ariz. 2010).

33. Do You Still Need a CCW Permit in Arizona?, Firearms Mastery Inst. (May 11, 2010), http://www.firearmsmastery.com/2010/05/do-you-still-need-an-arizona-ccw-permit/ [https://perma.cc/Y4JT-EHW3] ("With the passage of SB 1108, the Constitutional Carry Bill, Arizona became the third state to allow its citizens to legally carry a concealed weapon without a state issued permit.").

34. S. 1153, 49th Leg., 2d Reg. Sess. (Ariz. 2010); see About Statewide Knife Preemption, supra note 22.

35. See Moore v. Madigan, 702 F.3d 933, 942 (7th Cir. 2012) (discussing difficulty of finding reliable firearms statistics).

36. Arizona, Gun Ownership by State, CBS News, https://www.cbsnews.com/pictures/gunownership-rates-by-state/27/ [https://perma.cc/69ZZ-WJBJ] (last visited May 25, 2019).

37. Id. ("The gun ownership rate in Arizona is 32.3 percent.").

38. Kim Parker, Juliana Menasce Horowitz, Ruth Igielnik, J. Baxter Oliphant \& Anna Brown, America's Complex Relationship with Guns, PEW Research Center 22 (Jun 22, 2017), https://www.pewsocialtrends.org/wp-content/uploads/sites/3/2017/06/Guns-Report-FOR-

WEBSITE-PDF-6-21.pdf [https://perma.cc/4EPL-ZGB4] (finding that sixty-six percent of gun owners own more than one gun, with thirty-seven percent owning two to four guns and twentynine percent owning five or more guns). 
Arizona has issued 325,421 active $\mathrm{CCW}$ permits-one for every twenty-two Arizonans. ${ }^{39}$

These sweeping changes in the law, coupled with the increase in public carry of weapons, has created legal and logistical challenges for law enforcement in Arizona. Police officers are charged, first and foremost, with maintaining the safety and security of citizens in public, and a significant aspect of maintaining that safety is identifying individuals carrying weapons who have the power the injure themselves or others. But officers may not simply stop and disarm anyone carrying a gun or knife under the guise of protecting the public. ${ }^{40}$ Under the post-Terry Fourth Amendment, officers may only stop, detain, and search someone if they have reasonable suspicion that the person is engaged in criminal conduct. ${ }^{41}$ In Arizona, where public carry of virtually any weapon by virtually anyone is legal and affirmatively protected by statute, possession of a weapon alone does not sufficiently suggest criminal behavior to justify a stop. This reality leaves Arizona police officers in the unenviable position of divining which armed Arizonans are criminal threats to public safety and which are merely exercising their rights to public carry.

This section outlines the history of Arizona's evolution from a heavily regulated public carry state to a "constitutional carry" state, including the major legal challenges defining the contours of Arizona's weapons laws along the way. The section first briefly sketches the national trend towards permissive concealed carry laws and then places Arizona's concealed carry history within that broader context. It then discusses Arizona's uniquely permissive knife laws and the impact these laws have had on national lobbying efforts to deregulate blades. In doing so, this section implicitly diagnoses the "problem" facing police as they attempt to maintain safety and order on Arizona's streets and roadways.

39. Concealed Carry Statistics, supra note 1; Quick Facts: Arizona, U.S. CENSUS BUREAU https://www.census.gov/quickfacts/fact/table/az/PST045217 [https://perma.cc/RV2D-CSYS] (last visited Mar. 14, 2019) (estimating Arizona population of 7,016,270 as of July 1, 2017).

40. See Terry v. Ohio, 392 U.S. 1, 32-33 (1968) (Harlan, J., concurring) ("[I]f the frisk is justified in order to protect the officer during an encounter with a citizen, the officer must first have constitutional grounds to insist on an encounter, to make a forcible stop. ... [T] [Te person addressed . . certainly need not submit to a frisk for the questioner's protection."); United States v. Gray, 213 F.3d 998, 1000-01 (8th Cir. 2000) (finding protective frisk violated the Fourth Amendment because officers had no reasonable suspicion that the individual was engaged in criminal activity); United States v. Burton, 228 F.3d 524, 528-29 (4th Cir. 2000) (holding that an officer may not conduct a protective search to allay a reasonable fear that a suspect is armed without first having a reasonable suspicion to support an investigatory stop).

41. See Terry, 392 U.S. at 30. 


\section{A. The National Evolution of Concealed Carry Legislation}

American opinions about firearms have evolved significantly since the time Terry was decided in $1968 .^{42}$ Fifty years ago, the politics of firearm ownership and possession revolved around bipartisan agreement that public firearm possession should be strictly regulated. ${ }^{43}$ Much of this support stemmed from the assassinations of President John Kennedy, his brother Robert Kennedy, and Rev. Martin Luther King, $\mathrm{Jr}^{44}$ While earlier attempts at national gun control legislation failed, by 1968, Congress passed two landmark bills with broad bipartisan support: the Omnibus Crime Control and Safe Streets Act of 1968 and the Gun Control Act of 1968. These laws combined to significantly restrict interstate firearms transfer, strictly limit public firearms possession, require federal licensing for firearms dealers, prohibit most direct mail-order firearms sales, and expand the categories of persons prohibited from possessing firearms of any kind..$^{45}$

Of course, public attitudes about gun rights have changed dramatically since 1968. Reflecting this shift, states began relaxing restrictions on public firearm possession in significant numbers by the early 1980 s. ${ }^{46}$ Over the ensuing thirty years, states across the country loosened or eliminated entirely restrictions on public open and concealed carry of firearms. Advocates for

42. See, e.g., Guns, GaLluP, http://news.gallup.com/poll/1645/guns.aspx [https://perma.cc/39YX-FSTT] (last visited Mar. 14, 2019) (providing historical public opinion data about gun regulation). In one historical trend noted by Gallup, sixty percent of Americans supported the outright ban of handguns in 1959, but by October 2017 support had fallen to twentyeight percent. $I d$.

43. On August 8, 1967, the House of Representatives passed by a 378-23 margin the Omnibus Crime Control and Safe Streets Act of 1968, which among other things strictly limited interstate transfers for handguns and raised the minimum age to twenty-one for buying handguns. The Senate passed the bill on May 23, 1968, by a 72-4 margin. President Johnson signed it into law on June 19, 1968, nine days after Terry. See Pub. L. No. 90-351, 82 Stat. 197 (2018) (codified as amended at 34 U.S.C. $\$ \S 10101-10726(2018)$ ).

44. See Jon Michaud, The Birth of the Modern Gun Debate, THE NEw YORKER (Apr. 19, 2012), https://www.newyorker.com/books/double-take/the-birth-of-the-modern-gundebate [https://perma.cc/75CN-UEJW] (chronicling the history of the gun control debate in the years after the John Kennedy assassination); Steven Rosenfeld, The NRA Once Supported Gun Control, SALON (Jan. https://www.salon.com/2013/01/14/the_nra_once_supported_gun_control/ [https://perma.cc/5Z83-RDM8] (citing "[t] Martin Luther King, Jr. and Sen. Robert F. Kennedy [as] the tipping point" for federal gun control legislation, along with "several summers of race-related riots in American cities").

45. See supra note 43; Pub. L. No. 90-135, 82 Stat. 226 (1967) (codified as amended at 18 U.S.C. $\$ 921(2018))$.

46. See Clayton E. Cramer \& David B. Kopel, "Shall Issue": The New Wave of Concealed Handgun Permit Laws, 62 TENN. L. REv. 679, 680-86 (1995) (discussing history of concealed carry handgun legislation). 
these more permissive firearms possession and carry laws found support from the United States Supreme Court. In 1997, the Court held that federal background check requirement under the Brady Handgun Violence Prevention Act was unconstitutional. ${ }^{47}$ Then in 2008, the Court held for the first time that the Second Amendment protects an individual's right to possess a firearm for self-defense or any other lawful purpose,${ }^{48}$ and extended that protection in 2010 to the states via the Fourteenth Amendment's Due Process Clause ${ }^{49}$ These significant changes in public opinion, legislation, and constitutional law challenge the once-reasonable assumption that a public gun carrier is a dangerous lawbreaker.

Today, state public gun possession laws fall within one of four "right-tocarry" categories:

Unrestricted: State law allows individuals to carry concealed firearms for lawful purposes without a permit. ${ }^{50}$ These states are sometimes referred to by gun rights advocates as "constitutional carry" states. ${ }^{51}$

47. See Printz v. United States, 521 U.S. 898, 898 (1997).

48. See District of Columbia v. Heller, 554 U.S. 570 , 589 (2008); Lawrence Rosenthal, Second Amendment Plumbing After Heller: Of Standards of Scrutiny, Incorporation, WellRegulated Militias, and Criminal Street Gangs, 41 URB. LAW. 1, 6 (2009) (observing that Heller delivered a significant victory for gun rights advocates and "[i]mperiled [the] [c]ase for [g]un [c]ontrol").

49. See McDonald v. City of Chicago, 561 U.S. 742, 763-68, 776-78 (2010) (discussing the well-known doctrine of "selective incorporation," wherein only those most fundamental of constitutional rights apply to restrict the actions of both the federal and state governments, and recognizing the "fundamental" nature of individual right to keep and bear arms as one restricting the states).

50. See Brian Enright, Note, The Constitutional "Terra Incognita" of Discretionary Concealed Carry Laws, 2015 U. ILL. L. REV. 909, 918-25 (2015) (discussing types of concealed carry jurisdictions); see Kansas: Permitless Carry Bill to Receive Vote Tomorrow on Senate Floor, NAT'L RIFLE Ass'N: INST. FOR LEgIS. ACTION (Feb. 25, 2015), https://www.nraila.org/articles/20150225/kansas-permitless-carry-bill-to-receive-votetomorrow-on-senate-floor [https://perma.cc/BL7V-TEYV] (discussing pending "constitutional carry" or "permitless carry" legislation in Kansas).

51. CBS 13, Maine Lawmaker Submits 'Constitutional Carry' Bill, BANGOR DAILY News (Feb. 26, 2015), https://bangordailynews.com/2015/02/26/news/state/maine-lawmaker-submitsconstitutional-carry-bill/ [https://perma.cc/DY2L-RTBU]; see also Charles C.W. Cooke, Vermont: Safe and Happy and Armed to the Teeth, NAT'L REV. OnLINE: CORNER (Jun. 24, 2014, 8:21 PM), http://www.nationalreview.com/corner/396857 [https://perma.cc/7CNT-9Q69] (noting that "constitutional carry" is sometimes referred to as "Vermont carry" because Vermont for decades was the only state in the country that did not require a permit to carry a concealed firearm in public). 
Shall Issue: State law requires a license to carry a concealed firearm in public, but the granting of such licenses is nondiscretionary and subject only to meeting determinate criteria set forth in the law. ${ }^{52}$

May Issue: State law requires a license to carry a concealed firearm in public and provides the issuing entity with discretion over the issuance of a permit. $^{53}$ This discretion varies significantly from jurisdiction to jurisdiction. ${ }^{54}$

No Issue: State law does not allow any private citizen to carry a concealed handgun in public, with very few limited exceptions. ${ }^{55}$

As recently as 1988, forty states either prohibited the public possession of firearms (sixteen "no issue" jurisdictions) or tightly regulated such possession (twenty-four "may issue" jurisdictions) ${ }^{56}$ But by 1994, the year Arizona became a "shall issue" jurisdiction, over half of all states had either no or very few restrictions on concealed carry permitting. ${ }^{57}$

As of 2015, every state and the District of Columbia allow the public concealed carry of firearms. ${ }^{58}$ The vast majority of these states are now

52. See Enright, supra note 50, at 919-20 ("As the name suggests, shall-issue laws require the issuing authority to issue a permit to an applicant who meets delineated requirements. There is little to no discretion on the part of the issuing body."); see also Walter Rickshaw, What Is the Difference Between Shall Issue and May Issue?, CONCEAled CARRY Class, $\mathrm{http} / /$ www.concealedcarryclass.net/what-is-the-difference-between-shall-issue-and-may-issue/ [https://perma.cc/37LF-RGWM] (last visited Mar. 16, 2019); Nancy Thorne, What Is the Difference Between "May Issue", "Shall Issue", "No Issue" and "Unrestricted" Concealed Carry Laws?, NAT'L CARRY ACAD. (Aug. 29, 2016), https://www.nationalcarryacademy.com/mayissueshallissuenoissue/ [https://perma.cc/L7M32P99].

53. See Enright, supra note 50, at 921-23.

54. See id. at 921-22, $921 \mathrm{n} .118$ (observing that some "may-issue laws . . are applied more like shall-issue laws" (like Alabama), but "[o]ne of the strictest may-issue laws is found in New York").

55. See id. at 923-25 ("A no-issue state is one that requires, but does not issue, permits for public carry."); see also Rickshaw, supra note 52; Thorne, supra note 52.

56. In 1988, nine states were "shall issue" jurisdictions. See ALA. CODE $\$ 13 A-11-75$ (1988) (a may-issue law interpreted as a shall-issue law); CONN. GEN. STAT. § 29-28(a) (1988); FLA. STAT. § 790.06(2) (1988); IND. CODE § 35-47-2-3 (1988); ME. STAT. tit. 25, § 2003(1) (1988); N.D. CENT. CODE § 62.1-04-03(1) (1985); S.D. CoDIFIED LAWs $\S$ 23-7-7 (1986); Wash. Rev. CODE $\$ 9.41 .070$ (1988). Vermont was the lone "unrestricted" jurisdiction. Cooke, supra note 51.

57. Joseph A. Wegenka, Concealed Handgun Laws in the United States 26 (undated) (unpublished graduate applied project, Western Kentucky University) (available at https://www.wku.edu/mae/documents/econ596-wegenka.pdf [https://perma.cc/5267-XVKV]). Five states became shall issue jurisdictions in 1995: Nevada, Oklahoma, Arkansas, Virginia, and Utah. Id. at 26 tbl.1. Texas became a shall issue jurisdiction in 1996. Id.

58. Concealed Carry, Giffords L. CTR. TO Prevent Gun Violence, https://lawcenter.giffords.org/gun-laws/policy-areas/guns-in-public/concealed-carry/ 
unrestricted or shall-issue jurisdictions, in which there are little to no restrictions on an individual's ability to lawfully carry a firearm in public. ${ }^{59}$

\section{B. Arizona: From Gun Control to "Constitutional Carry"}

Arizona's journey to becoming among the most permissive gun possession states actually began with Arizona providing some of the stiffest restrictions on public possession. As early as 1901, "carrying concealed weapons was prohibited" in the Arizona Territory. ${ }^{60}$ "In fact, the 1913 Arizona Penal Code [after statehood in 1912] mirrored the 1901 Penal Code of the Arizona Territory, providing 'it shall be unlawful for any person . . . to have or carry concealed on ... his person, any pistol or other firearm ...." At the time, few states (and even fewer western territories) had statutory bans on concealed carry. This strict ban on public concealed weapons possession was codified at A.R.S. section 13-3102, and remained in force until the ban was lifted in $2010 .{ }^{62}$

[https://perma.cc/VQ3U-VNBG] (last visited May 25, 2019) ("Every state-as well as the District of Columbia-allows the carrying of concealed weapons in some form.").

59. See Alaska Stat. \$ 18.65.700 (2019); ArIZ. ReV. STAt. ANN. \$ 13-3112 (2019); ARK. Code AnN. § 5-73-309 (2019); Colo. Rev. STAT. § 18-12-203(1) (2019); Fla. Stat. § 790.06(2) (2019); GA. CODE ANN. § 16-11-129 (2019); IDAHO CODE $§ 18-3302$ (1) (2019); IND. CODE $\S 35-$ 47-2-3 (2019); IOWA Code § 724.7(1) (2019); Kan. STAT. ANN. § 75-7c03 (2019); Ky. ReV. STAT. ANN. § 237.110(4) (West 2019); LA. STAT. ANN. § 40:1379.3(A)(1) (2019); ME. STAT. tit. 25, § 2003(1) (2019); Mich. COMP. LAWs § 28.425b(7) (2019); MinN. STAT. § 624.714(2)(b) (2019); Miss. CODE ANn. § 45-9-101(6)(c) (2019); Mo. REV. STAT. § 571.101(1) (2019); MONT. CODE ANN. § 45-8-321(1) (2019); Neb. Rev. Stat. \$§ 69-2430(3)(b), -2433 (2019); NeV. ReV. STAT. § 202.3657(3) (2019); N.H. REV. STAT. ANN. § 159:6(I)(a) (2019); N.M. STAT. ANN. § 2919-4(A) (2019); N.C. Gen. Stat. \$14-415.12 (2019); N.D. Cent. Code §62.1-04-03(1) (2019); OHto Rev. CODE AnN. \$2923.125(D) (West 2019); OKLa. Stat. tit. 21, $\S 1290.12(A)(12)$ (2019); OR. REv. STAT. $\$ 166.291$ (2019); 18 PA. CONS. STAT. $§ 6109(\mathrm{e})(1)$ (2019); S.C. CODE ANN. \$23-31-215(A) to (C) (2019); S.D. CoDIFIED LAWs $\$ 23-7-7$ (2019); Tenn. Code ANN. \$39-17-1351 (2019); TeX. Gov't CODE ANN. \$411.172 (West 2019); UTAH CODE ANN. \$ 53-5-704 (West 2019); VA. CODE ANN. \$ 18.2-308.02 (2019); WASH. REV. CODE $\S 9.41 .070$ (2019); W. VA. CODE § 61-7-4 (2019); WIS. STAT. § 175.60 (2019); WYO. STAT. ANN. \$6-8-104(b) (2019). In addition to these forty state statutes, Alabama and Connecticut "by statute allow considerable police discretion but, in practice, commonly issue permits to applicants who meet the same standards as in shall-issue states." Drake v. Filko, 724 F.3d 426, 441 n.5 (3d Cir. 2013) (Hardiman, J., dissenting); see also AlA. CoDE § 13A-11-75 (2019); CONN. GEN. STAT. § 29-28(a) (2019).

60. State v. Moerman, 895 P.2d 1018, 1022 (Ariz. Ct. App. 1994) ("Immediately before and after the adoption of Arizona's Constitution, carrying concealed weapons was prohibited.").

61. Id; see Ariz. Penal Code $\$ 426$ (1913); Rev. Stat. Ariz. Territory, Ariz. Penal CODE $\$ 382(1901)$.

62. Moerman, 895 P.2d at 1022; see infra note 81 and accompanying text. 
The delegates at the 1910 Arizona Constitutional Convention did adopt (and the people did ratify) a provision to the Arizona Constitution stating that, "[t]he right of the individual citizen to bear arms in defense of himself or the State shall not be impaired," but this right was anything but absolute. ${ }^{63}$ Two alternative proposals expressly giving the legislature the right to regulate or prohibit concealed carry were narrowly rejected, arguably suggesting that the delegates intended to allow $\mathrm{CCW} .{ }^{64}$

Arizona gun rights advocates made this exact argument in State $v$. Moerman, a 1994 Arizona Court of Appeals case in which two defendants challenged their convictions for illegally possessing concealed handguns in public by claiming A.R.S. section 13-3102 violated the Arizona Constitution. ${ }^{65}$ But the Court rejected the claim that "these 'rejected amendments' support Defendants' argument that the framers of the Arizona Constitution intended ... to confer an absolute right to bear arms." Court observed that the adopted language itself provides a qualified right "in which 'the right of the individual citizen to bear arms in defense of himself or the State shall not be impaired."'67 The Court also noted that, given the existence of a concealed carry ban prior to the adoption of the Arizona Constitution, "the framers could have rejected th[ese] amendment[s] to avoid

63. Moerman, 895 P.2d at 1022 ("First, we note that Article II, section 26 itself provides not an absolute right, but instead a qualified one in which "the right of the individual citizen to bear arms in defense of himself or the State shall not be impaired ...."). The delegates narrowly rejected two alternative wordings that explicitly granted the legislature the right to continue regulating or prohibiting concealed carry. Richard D. Coffinger, Arizona's 100-Year Conflict over Concealed Weapons, ARIZ. ATT'Y, Feb. 2012, at 40, 41-42. These alternatives were:

Proposition No. 104, subsection 9: 'The right of the people to keep and bear arms shall not be denied or abridged; but this section shall not be construed to deny the right of the law-making power to regulate or prohibit the carrying of concealed weapons upon the person.' Proposition No. 116, subsection 17: 'That the right of no citizen to keep and bear arms in defense of his home, person or property, or in aid of the civil power, when thereto legally summoned, shall be called in question; but nothing herein contained is intended to justify the practice of wearing concealed weapons.'

Id. at 42 .

64. See The Records of the Arizona Constitutional Convention of 1910678 (John S. Goff ed., 1991) (explaining that three alternative proposals were considered, including one that stated, in part, "But the legislature shall have the right to regulate the wearing of weapons to prevent crime," and another stating "The people shall have the right to bear arms for their safety and defense, but the legislature shall regulate the exercise of this right by law").

65. Moerman, 895 P.2d at 1020.

66. Id. at 1022 .

67. Id. 
redundancy, or because they deemed it to be unnecessary." ${ }^{268}$ The Court concluded with a full-throated defense of Arizona's concealed carry ban, citing with approval prior case law that A.R.S. section 13-3102 "was drafted to "protect[] the public by preventing an individual from having on hand a deadly weapon of which the public is unaware, and which an individual may use in a sudden heat of passion." ${ }^{69}$

In dissent, Judge Weisberg found a 1970 amendment to Arizona's CCW ban unconstitutionally vague. This amendment exempted from the ban weapons that were "carried in a belt holster which holster is . . partially visible, or is carried in a scabbard or case designed for carrying weapons."70 Judge Weisberg maintained that a "case designed for carrying weapons" arguably could include the "fanny-packs" in which the defendants kept their handguns, and suggested that "the legislature ought to require that the holster, scabbard, or case be readily identifiable as containing a weapon."71 Thus, while dissenting from the opinion, Judge Weisberg actually advocated tighter restrictions than those contained in the existing statute.

Reflecting the changing attitudes about public gun possession in Arizona and throughout the country, reaction to the Moerman decision was swift and negative. Rather than taking Judge Weisberg's advice to more clearly restrict public gun possession, the Arizona Legislature enacted A.R.S. section 133112 , creating the first concealed carry weapons permitting process in the state and exempting anyone from prosecution who obtained a permit. ${ }^{72}$ This permitting process gave local authorities significant discretion in deciding whether to grant or deny a permit, thus making Arizona a "may issue" jurisdiction, ${ }^{73}$ but it nevertheless reflected a sea change in the public arming of Arizonans.

68. $I d$.

69. Id. (quoting Dano v. Collins, 802 P.2d 1021, 1023 (Ariz. Ct. App. 1990)). "This statute is narrowly drawn and ... it regulates only the manner in which individuals may exercise their right to bear arms. Although A.R.S. section 13-3102 may limit this right, it neither frustrates nor impairs it." Id.

70. Coffinger, supra note 63, at 44; see Moerman, 895 P.2d at 1025 (Weisberg, J., dissenting); see also S. 12, 29th Leg., 2d Reg. Sess. (Ariz. 1970). Original versions of Senate Bill 12 "would have permitted a woman to carry a weapon in her purse for self-defense," but the provision was removed after patronizing lobbying from police chiefs, "who contended a woman would be better protected if she carried in her purse a chemical, such as mace or pepper spray . . . because great skill is not required to use them." Coffinger, supra note 62, at 44 .

71. Moerman, 895 P.2d at 1025 (Weisberg, J., dissenting).

72. H.B. 2131, 41st Leg., 2d Reg. Sess. (Ariz. 1994) (enacted); ARIz. REv. STAT. ANN. § 133112 (2019); Coffinger, supra note 63, at 45.

73. See Enright, supra note 50, at 921-23. 
Two significant events a decade later accelerated the deregulation of public concealed carry in Arizona. First, in 2008, the United States Supreme Court ruled for the first time that the Second Amendment to the United States Constitution protected an individual's right to bear arms for self-defense, not merely the right to bear arms as part of a state militia. ${ }^{74}$ Second, in early 2009, President Obama appointed Arizona Governor Janet Napolitano to serve as the Secretary of Homeland Security, allowing Arizona Secretary of State Jan Brewer as first in the line of succession to become governor. ${ }^{75}$

Brewer, a longtime member of the National Rifle Association and the Arizona Rifle and Pistol Association, immediately set out to relax Arizona's gun laws. ${ }^{76}$ Six months after taking office, Governor Brewer signed Senate Bill 1113, allowing Arizonans to carry concealed guns in bars and restaurants as long as they did not consume alcohol, unless the business specifically posted a sign in accordance with Arizona law that guns are not permitted on the premises. ${ }^{77}$ She further expanded the right of $\mathrm{CCW}$ permit holders with Senate Bill 1168, which banned property owners from prohibiting the storage of firearms in locked vehicles parked on their lots. ${ }^{78}$

Most significantly, however, was Governor Brewer's action on April 16, 2010, when she signed Senate Bill 1108 making it legal for anyone over the age of 21 to carry a concealed deadly weapon without a permit. ${ }^{79}$ Overnight, Arizona went from a relatively strict "may issue" state to the third "constitutional carry" state in the nation, after Vermont and Alaska ${ }^{80}$ When then-Senator Russell Pearce sponsored the bill in February 2010, he stated

74. See District of Columbia v. Heller, 554 U.S. 570,589 (2008). Because the District of Columbia ordinance struck down in Heller was federal, the decision did not apply to states. In State v. Sieyes, 225 P.3d 995 (Wash. 2010), the Washington Supreme Court held that the Second Amendment right to bear arms applies to the state through the Due Process Clause of the Fourteenth Amendment. The United States Supreme Court affirmed that view in McDonald $v$. City of Chicago. 561 U.S. 742,791 (2010).

75. See Paul Davenport, Brewer Running for Full Term as Ariz. Governor, AZCENTRAL.COM (Nov. 5 , 2009 ,

11:15 AM),

http://archive.azcentral.com/news/election/azelections/articles/2009/11/05/20091 105arizonagovernor-ON.html [https://perma.cc/5TN8-XLJ3].

76. See Protecting Second Amendment Rights, JAN BREWER GOVERnor, https://web.archive.org/web/20100324121837/http://www.janbrewer.com/where-istand/protecting-second-amendment-rights [https://perma.cc/9QR8-6W6W] (last visited Mar. 3, 2019) (position statement of Jan Brewer regarding gun rights, describing her as a "[p]roud member and longtime supporter of National Rifle Association[,]" and "[p]roud member and longtime supporter of the Arizona Rifle and Pistol Association").

77. S. 1113, 49th Leg., 1st Reg. Sess. (Ariz. 2009).

78. S. 1168, 49th Leg., 1st Reg. Sess. (Ariz. 2009).

79. S. 1108, 49th Leg., 2d Reg. Sess. (Ariz. 2010).

80. See supra note 33 and accompanying text. 
simply that the law would reflect what Arizona's and the nation's founders intended: "If you are a law-abiding citizen, you have a right to carry." ${ }^{81}$ In signing the measure, Governor Brewer echoed this sentiment: "As governor I have pledged a solemn and important oath to protect and defend the Constitution.... I believe this legislation not only protects the Second Amendment rights of Arizona citizens, but restores those rights as well." ${ }^{22}$

In 2013, Governor Brewer defended the law against attempts by municipalities to enact their own concealed carry regulations, signing into law a firearms preemption statute requiring all firearms regulation to happen at the state level. ${ }^{83}$ In the same law, she expressly prohibited local governments from maintaining a list of citizens who possess a firearm. ${ }^{84}$ Both actions, while lauded by gun rights advocates, significantly limited the flexibility of local law enforcement in how they are able to handle firearms issues unique to their municipalities.

As reflected in the statistics above, the signing of this legislation not only helped promote an already-active gun culture in Arizona, but led to an increase in the number of concealed handguns carried in public. This dramatic change in Arizona law and culture led the influential gun rights group Guns \& Ammo to rank Arizona as the "Best State for Gun Owners" in a 2014 study examining each state's gun possession laws, gun and ammunition purchase laws, self-defense laws, and availability and access to shooting sports. ${ }^{85}$ Arizona has retained the top spot for five consecutive years, with Guns \& Ammo stating in its 2018 survey that:

81. Alia Beard Rau, Push Is on to Ease Arizona's Gun Laws, ARIZ. Republic (Feb. 3, 2010, 12:00 AM), http://archive.azcentral.com/arizonarepublic/news/articles

/2010/02/03/20100203weaponbills0203.html.

82. Evan Wyloge, Brewer Signs Law to Loosen Restrictions on Carrying Concealed Weapons, ARIZ. CAPITOL TIMES (Apr. 16, 2010), https://azcapitoltimes.com/news/2010/04/16/brewer-signs-law-to-loosen-restrictions-oncarrying-concealed-weapons/ [https://perma.cc/7L9D-CV3D].

83. H.R. 2326, 51st Leg., 1st Reg. Sess. (Ariz. 2013) ("Except as provided in subsection F of this section, a political subdivision of this state shall not enact any ordinance, rule or tax relating to the transportation, possession, carrying, sale, transfer . . . or use of firearms or ammunition ... ."); Arizona: Governor Brewer Signs Two Pro-Gun Reforms into Law, NAT'L Rifle Ass'N: Inst. FOR LEGIS. ACTION (May 1, 2013), https://www.nraila.org/articles/20130501/arizona-governorbrewer-signs-two-pro-gun-reforms-into-law [https://perma.cc/5XP4-HMU4].

84. Ariz. H.R. 2326 ("A political subdivision of this state shall not require or maintain a record in any form ... including a list, log or database, of . . any identifying information of a person who owns, possesses, purchases, sells or transfers a firearm.").

85. Best States for Gun Owners 2014, Guns \& AMmo (May 22, 2014), $\mathrm{http}: / /$ www.gunsandammo.com/editorial/best-states-for-gun-owners-2014/249668 [https://perma.cc/H6DB-PYQS]. 
An effort to weaken Arizona's firearm law preemption statute was defeated this session, keeping the state at the number one position in our survey for the fifth straight year. Arizona receives 10 points across the board thanks to its permitless (and permitted) carry law, a strong preemption statute, excellent use-of-force laws, and a lack of restrictions on individual firearms and accessories. Beyond a great set of laws, Arizona has one of the most thriving shooting cultures in the nation, a factor that helps it maintain its spot at the top of our list. Anti-gun groups rank Arizona as the worst state in the nation in terms of gun laws; we say it's the best. ${ }^{86}$

\section{Heller and McDonald in Arizona}

Governor Brewer's pronouncement that she was "protect[ing] the ... rights of Arizona citizens" 87 by eliminating concealed permitting requirements was arguably buttressed by the United States Supreme Court's decision two years earlier in District of Columbia v. Heller ${ }^{88}$ Prior to Heller, the Court had never expressly opined on the scope of the Second Amendment's protections for the individual right to "keep and bear arms" as opposed to the right of "well-regulated militias" to do so. ${ }^{89}$

Writing for the majority, Justice Scalia rejected the restrictive view that the Second Amendment only granted the people the right to form an armed militia. ${ }^{90}$ Instead, he determined that the Amendment protected an individual right to keep and bear arms that included the right to self-defense with a firearm and the right to have a working firearm in the home. ${ }^{91}$

86. Keith Wood, Best States for Gun Owners (2018), Guns \& AMMO (Oct. 31, 2018), http://www.gunsandammo.com/editorial/best-states-for-gun-owners-2018/327233

[https://perma.cc/X8XX-MSWR].

87. Wyloge, supra note 82.

88. District of Columbia v. Heller, 554 U.S. 570,589 (2008).

89. United States v. Booker, 644 F.3d 12, 22 (1st Cir. 2011) ("In Heller, the Supreme Court found for the first time that this language secured an individual, and not just a collective, right to bear arms.").

90. See Heller, 554 U.S. at 582 ("The phrase to 'keep arms' was not prevalent in the written documents of the founding period that we have found, but there are a few examples, all of which favor viewing the right to 'keep Arms' as an individual right unconnected with militia service.").

91. See id. at 599 (finding that "self-defense ... was the central component of the right itself"). Heller left open the question of whether the Second Amendment's protections are incorporated by the Due Process Clause of the Fourteenth Amendment, given Washington, D.C.'s special status as a federal district. Id. at $620 \mathrm{n} .23$. The Court addressed that issue two years later in McDonald v. City of Chicago, finding that the Second Amendment did in fact apply to the states as well as the federal government. 561 U.S. 742, 772 (2010). 
However, while the Court recognized that some important limitations existed on this right, it declined to define the contours of those limitations. ${ }^{92}$ Litigation across the country immediately commenced in federal court over whether Heller protected the right to public open or concealed carry of firearms. In the Ninth Circuit, a three-judge panel considered California's broad prohibition against the open or concealed carriage of a handgun in public locations. ${ }^{93}$ Relying on Heller, the panel found that "the Second Amendment does require that the states permit some form of carry for selfdefense outside the home," even if the Second Amendment does not "require[] the states to permit concealed carry." contentious public controversy over the case, the Ninth Circuit reversed the panel's decision after a rehearing en banc, holding that "the Second Amendment does not protect, in any degree, the carrying of concealed firearms by members of the general public." 95

This decision still left open the question of whether a specific type of public carry - open — was specifically protected by the Second Amendment. The Ninth Circuit answered that question in Young v. Hawaii, when it held that "the Second Amendment encompasse[d] a right to carry firearms openly in public for self-defense" because " "bear' implies" such a right. ${ }^{96}$ In striking down Hawaii's complete ban on public handgun possession, the court also confirmed that "the concealed carry of firearms categorically falls outside such [Second Amendment] protection," thus leaving that right up to state constitutions and legislatures. ${ }^{97}$

Perhaps not surprisingly in a state protecting by statute the near absolute right to carry firearms in public_-openly or concealed—Arizona state courts

92. See Heller, 554 U.S. at 626-27 ("[N]othing in our opinion should be taken to cast doubt on longstanding prohibitions on the possession of firearms by felons and the mentally ill, or laws forbidding the carrying of firearms in sensitive places such as schools and government buildings, or laws imposing conditions and qualifications on the commercial sale of arms."). See also id. at 627 (limiting the right to arms that are "in common use," leaving it open to states to regulate and ban certain types of assault weapons and weapons commonly useful only in military service).

93. Peruta v. Cty. of San Diego, 742 F.3d 1144 (9th Cir. 2014), rev'd en banc, 824 F.3d 919 (9th Cir. 2016).

94. Id. at 1172 .

95. Peruta, 824 F.3d at 942; see also Recent Case, Peruta v. County of San Diego-Ninth Circuit Holds That Concealed Carry Is Not Protected by the Second Amendment, 130 HARV. L. REV. 1024, 1028 (2017) (observing the Ninth Circuit confirmed that "concealed carry is not protected by the Second Amendment").

96. 896 F.3d 1044, 1050, 1053 (9th Cir. 2018), reh'g granted en banc, 915 F.3d 681 (9th Cir. 2019) (mem.).

97. Id. at 1068 . 
have only cited the Heller decision three times. ${ }^{98}$ None of these decisions considered the constitutional questions at issue in Heller nor otherwise the right to bear arms in public. ${ }^{99}$ Arizona federal district courts applying Heller and its progeny have relied on Heller's emphasis that Second Amendment rights are "not unlimited" 100 to reject constitutional challenges to Arizona's "prohibited possessor" statutes ${ }^{101}$ and their federal counterpart, as well as to Arizona's "weapons misconduct statute" prohibiting reckless conduct. ${ }^{102}$

\section{The Unique Case of Arizona's "Blade" Laws}

Though less well-known and polarizing than the National Rifle Association and other gun rights advocacy groups, an active knife enthusiast community has also successfully lobbied Arizona and other states to enact increasingly permissive knife possession laws. ${ }^{103}$ Led by the American Knife $\&$ Tool Institute (AKTI), ${ }^{104}$ these groups fund lobbying efforts to loosen restrictions on public knife possession, to broaden the scope of "blades" permitted to be carried in public, and to remove knives and related instruments from lists of "prohibited deadly weapons" in state statutes. ${ }^{105}$ As of December 3, 2018, AKTI's "Legislation" page listed no fewer than eighteen pending bills sponsored at AKTI's request to loosen restrictions on

98. See State ex rel. Brnovich v. City of Tucson, 399 P.3d 663, 676 (Ariz. 2017) (discussing separation of powers issue related to state statute preempting local ordinances regarding destruction of firearms); Gerald M. v. Dep't of Child Safety, No. 2 CA-JV 2015-0130, 2016 Ariz. App. Unpub. LEXIS 552, at *33 (Ariz. Ct. App. May 4, 2016) (Howard, J., dissenting) (considering child custody matter); Pinal Cty. Bd. of Supervisors v. Georgini, 334 P.3d 761, $766-$ 76 (Ariz. Ct. App. 2014) (rejecting claim that due process requires appointment of counsel to indigent party seeking restoration of forfeited firearms possession rights).

99. See supra note 98 and accompanying text.

100. Lewis v. Ryan, No. CV-17-00220-PHX-JAT (BSB), 2017 U.S. Dist. LEXIS 216584, at *31 (D. Ariz. Sept. 22, 2017).

101. Swartz v. Ryan, No. CV-12-0023-TUC-FRZ (BPV), 2014 U.S. Dist. LEXIS 68466, at *39-40 (D. Ariz. Apr. 15, 2014).

102. Id.

103. See About the American Knife \& Tool Institute, AM. KNIFE \& ToOL Inst., https://www.akti.org/about/ [https://perma.cc/5FXT-WBRS] (last visited Mar. 7, 2019) (describing the organization's mission "to ensure that Americans will always be able to make, buy, sell, own, carry and use knives and edged tools" by "promot[ing] . . reasonable, responsible and consistent knife legislation to elected officials").

104. $I d$.

105. Follow Current Knife Legislation, AM. KNIFE \& ToOL InST., https://www.akti.org/follow-current-knife-legislation/ [https://perma.cc/285H-DPUX] (last visited Mar. 7, 2019) ("AKTI has been successful in removing, clarifying and correcting poorly conceived and ambiguous legislation and educating legislators on knife issues on behalf of the entire knife community."). 
knife possession. ${ }^{106}$ Two federal bills - one which would repeal the Federal Switchblade Act of $1958^{107}$ and one dubbed the "Knife Owners' Protection Act"108 — would virtually eliminate restrictions on interstate sale of knives and would require national reciprocity by "protect[ing] law abiding knife owners traveling between states from conflicting state knife laws." 109

One of the initiatives supported by AKTI and other knife rights groups is statewide preemption, wherein the state government would act as the sole authority on knife laws. ${ }^{110}$ Taking the position that "knife owners should not be expected to know and understand knife laws in multiple ... jurisdictions where they may travel within their own state," AKTI has successfully lobbied for knife preemption laws in eleven states, all since $2010 .{ }^{111}$

The first state to enact statewide knife preemption laws was Arizona. ${ }^{112}$ In fact, Governor Brewer signed the nation's first knife preemption law on the same day that she signed Arizona's "constitutional carry" law, transforming the state indisputably into the most permissive public carry jurisdiction in the country with two strokes of the pen. ${ }^{113}$ This knife preemption law, codified at A.R.S. section 13-3120, accomplishes three primary objectives. First, it clearly prohibits any local government from "enact[ing] any ordinance, rule or tax relating to the transportation, possession, carrying, ... or use of a knife or knife making components in th[e] state." 114 Second, it defines "knife" incredibly broadly as "a cutting instrument[,] includ[ing] a sharpened or

106. $I d$.

107. 15 U.S.C. $\S \S 1242-1244$ (2018) (prohibiting the interstate transfer of automatic switchblades); see also 155 CONG. REC. 13, 17198 (2009) (observing the "commonly known" title "Federal Switchblade Act").

108. Knife Owners' Protection Act (KOPA), AM. KNIFE \& ToOL InST., https://www.akti.org/knife-owners-protection-act/ [https://perma.cc/22Z7-E29Q] (last visited Mar. 7, 2019) (summarizing need to pass a federal law that would protect knife owners "while traveling with their knives in the U.S.").

109. Follow 2017 Knife Legislation, AM. KNIFE \& ToOL InsT., https://www.akti.org/news/follow-2017-knife-legislation/ [https://perma.cc/AAQ8-DSL7] (last visited Mar. 7, 2019).

110. See About Statewide Knife Preemption, supra note 22 ("The majority of states have firearms preemption laws enacted as the result of the National Rifle Association's campaign to ensure consistency of laws for gun owners. We suggest to legislators to include knives into these preemption laws, where appropriate. Legislators are encouraged to contact the American Knife \& Tool Institute for assistance with wording or advice on knife legislation.").

111. Id. ("These states have knife preemption laws enacted: Alaska (since 2013), Arizona (since 2010), Georgia (since 2012), Kansas (since 2013), Montana (since 2019)New Hampshire (since 2011), Oklahoma (effective November 1, 2015), Tennessee (since 2013), Texas (effective September 1, 2015), Utah (since 2011), Wisconsin (effective February, 2016).").

112. Id.

113. S. 1153, 49th Leg., 2d Reg. Sess. (Ariz. 2010).

114. ARIz. ReV. StAT. ANN. § 13-3120(A) (2019). 
pointed blade."115 The effect of this definition is to broadly preempt regulation of any type of bladed instrument no matter how dangerous, including swords, balisongs, bowie knives, gravity knives, maces, stilettos, or "knives of any length." 116

Third, this preemption statute implicitly legalized the possession, sale, and public concealed carry of any bladed instrument. ${ }^{117}$ At the time Arizona enacted this preemption statute, no state laws existed creating either a per se prohibition against certain categories of knives or restricting the public open or concealed carry of such instruments. ${ }^{118}$ No such laws have been enacted in the eight years since the preemption law was signed ${ }^{119}$ To date, the only state law regulating the concealment and carrying of "weapons" at all is A.R.S. section 13-3102, the same law that made Arizona a "constitutional carry" state. ${ }^{120}$ That law prohibits only the "carrying [of] a deadly weapon except a pocket knife concealed on his person ... [i]n the furtherance of a serious offense . . . or . . if the person is under twenty-one years of age." ${ }^{21}$ In other words, concealed carry of knives is illegal only to the extent that an Arizonan is committing a crime with the knife.

While nine other states have since enacted knife preemption laws, all of these states have at least some statewide restriction on the possession and use of certain types of dangerous blades. Arizona stands alone in its permissiveness regarding knife possession. Unsurprisingly, knife rights groups recognize Arizona as a haven for blade possession. ${ }^{122}$ As one enthusiast correctly observed,

If you live in Arizona you are in luck[;] Arizona has the best knife laws of all 50 states. .. . Basically, you can own any type of blade you want and carry it concealed or in the open without worry.... In 2011 the State of Arizona preempted all municipal laws and, basically, made every type of knife legal. ${ }^{123}$

115. Id. $\$ 13-3120(\mathrm{~F})(1)$.

116. Arizona Knife Laws, KNIFE UP, https://knifeup.com/arizona-knife-laws [https://perma.cc/Y5PX-ZNAF] (last visited Mar. 13, 2019) [hereinafter KNIFE UP]; see Marc Lacey, Pushing a Right to Bear Arms, the Sharp Kind, N.Y. TIMES (Dec. 4, 2010), https://www.nytimes.com/2010/12/05/us/05knives.html?mtrref=www.google.com\&gwh=05F98 D91278502548B91B92B3A48F5A3\&gwt=pay [https://perma.cc/BAR8-6Z7H].

117. See KNIFE UP, supra note 116.

118. Arizona Knife Laws, supra note 21.

119. Id.

120. ARIZ. REv. STAT. ANN. § 13-3102 (2019) ("[m]isconduct involving weapons; defenses; classification; definitions").

121. Id. $\S 13-3102(\mathrm{~A})$.

122. See KNIFE Up, supra note 116.

123. Id. 
The enactment of this tapestry of laws broadly permitting the public concealed carry of knives and handguns stands as an unqualified victory for sporting enthusiasts and staunch Second Amendment advocates in Arizona. But these laws have complicated matters immeasurably for one prominent group of public weapons possessors: Arizona's police officers. Law enforcement personnel are charged with protecting the public by, among other things, identifying and neutralizing potentially dangerous individuals before they can commit violent acts against other citizens. But in a state that allows virtually all citizens to carry open or concealed lethal weapons in public, officers increasingly have difficulty discerning which public weapons possessors pose a dangerous criminal threat and which simply are exercising their statutory rights. The next two sections confront this growing problem, first by analyzing weapons possession through the "stop and frisk" lens, and then by exploring conflicting case law regarding when an officer should be allowed to search and disarm a public weapon carrier.

\section{II. "REASONABLE SUSPICION" AND POLICING A HEAVILY ARMED ARIZONA}

For much of this nation's history, police investigative authority was curtailed largely by the Fourth Amendment's requirement that officers obtain a warrant based upon probable cause. ${ }^{124}$ But the Supreme Court's decision in Terry v. Ohio in 1968 radically shifted the focus of courts away from warrant requirements and towards whether officers were acting reasonably in their interactions with individuals. ${ }^{125}$ Today, the "Terry stop," often known as a "stop and frisk," is a ubiquitous and pervasive police tactic requiring only a "reasonable suspicion" that an individual is engaged in criminal activity and is "armed and presently dangerous." 126 This broad expansion of police power forever altered the nature, scope, and number of law enforcement interactions with citizens.

124. See 1 Joshua Dressler \& Alan C. Michaels, Understanding Criminal PROCEDURE 261-62 (6th ed. 2013) (observing that the Warren Court criminal procedure cases of the late 1960s changed the focus of the Fourth Amendment from warrants based on probable cause to a "general Fourth Amendment standard of "reasonableness").

125. Id. ("[Terry] provided the impetus, as well as the framework, for a move by the Supreme Court away from the proposition that 'warrantless searches are per se unreasonable,' to the competing view that the appropriate test of police conduct 'is not whether it is reasonable to procure a search warrant, but whether the search was reasonable." (citations omitted)).

126. Terry v. Ohio, 392 U.S. 1, 28-30 (1968). 
When the Court decided Terry in 1968, Arizona prohibited the public concealed possession of firearms. ${ }^{127}$ That prohibition continued, with some exceptions, until 2010. ${ }^{128}$ Thus, one can understand why an Arizona officer reasonably may have suspected criminal activity was afoot when she observed, discovered, or received a tip about an individual's possession of a firearm in public. That possession, by itself, was criminal. ${ }^{129}$ This logic, combined with the once "nearly unanimous agreement that to be armed was to be dangerous," provided the necessary justification to conduct an automatic frisk of public gun possessors. ${ }^{130}$ But in Arizona's rapidly changing, gun-friendly deregulatory environment, these assumptions require reconsideration.

This section defines the contours of current stop and frisk jurisprudence, the problematic application of reasonable suspicion to a heavily armed Arizona populace, and the questionable efforts of the Arizona legislature to resolve this problem through its "duty to inform" laws.

\section{A. The Stop and Frisk Paradigm}

"The Fourth Amendment protects the right of people to be free from "unreasonable searches and seizures."'131 While Fourth Amendment jurisprudence has long focused on the warrant requirement, Terry shifted

the Supreme Court away from the proposition that 'warrantless searches are per se unreasonable,' to the competing view that the appropriate test of police conduct 'is not whether it is reasonable to procure a search warrant, but whether the search was reasonable. ${ }^{132}$

In Terry, the Court observed that the Fourth Amendment protects only against unreasonable searches and seizures, and thus authorizes searches and seizures based on less than a warrant or probable cause. ${ }^{133}$ The Court defined

127. See supra Section I.B.

128. S. 1108, 49th Leg., 2d Reg. Sess. (Ariz. 2010).

129. See Bellin, supra note 19 , at 31 (describing the widely held "assumption that a person carrying a concealed weapon was engaged in the crime of unlawful weapons possession").

130. Wilkins, supra note 19, at 1170 (quoting Bellin, supra note 19, at 32) (describing the "blanket assumption of dangerousness" under which most officers and courts traditionally operated with respect to gun possessors).

131. State v. Serna, 331 P.3d 405, 407 (Ariz. 2014) (quoting U.S. ConST. amend. IV).

132. DRESSLER \& MiCHAELS, supra note 124, at 262 (citations omitted); see also Terry v. Ohio, 392 U.S. 1, 11 (1968) (holding that lawful police encounters can exist "which do[] not depend solely upon the voluntary cooperation of the citizen and yet which stop[] short of an arrest based upon probable cause").

133. Terry, 392 U.S. at 9 (quoting Elkins v. United States, 364 U.S. 206, 222 (1960)). 
reasonableness as an objective test from the officer's perspective: "would the facts available to the officer at the moment of the seizure or the search 'warrant a man of reasonable caution in the belief' that the action taken was appropriate?" 134 Moreover, the Court found that an officer could initiate a search of a lawfully stopped suspect for "the protection of the police officer and others nearby," so long as it was "confined in scope to an intrusion reasonably designed to discover guns, knives, clubs, or other hidden instruments for the assault of the police officer." ${ }^{135}$ Attempting to limit this expansion of police search power, the Court explained that this pat down of the outer clothing "by no means authorize[d] a search for contraband, evidentiary material, or anything else in the absence of reasonable grounds to arrest. Such a search is controlled by the requirements of the Fourth Amendment, and probable cause is essential." ${ }^{136}$

"Thus, Terry created a two-pronged" test. ${ }^{137}$ Each prong is analyzed separately; the satisfaction of one prong cannot serve as justification for the second prong. Under the first prong, an officer may stop an individual (the seizure) if she has reasonable suspicion of criminal activity. ${ }^{138}$ Under the second prong, an officer may frisk the individual (the search) if she has reasonable suspicion that the person "is armed and presently dangerous to the officer or to others." ${ }^{139}$ Because these analyses are distinct, an officer may reasonably suspect a person is committing a crime but lack the requisite suspicion that the individual is armed and dangerous, and vice versa. ${ }^{140}$

134. Id. at 21-22 (citations omitted) ("II]n justifying the particular intrusion the police officer must be able to point to specific and articulable facts which, taken together with rational inferences from those facts, reasonably warrant the intrusion. ... If subjective good faith alone were the test, the protections of the Fourth Amendment would evaporate, and the people would be 'secure in their persons, houses, papers, and effects,' only in the discretion of the police.").

135. Id. at 29.

136. Id. at $16 \mathrm{n} .12$ (quoting State v. Terry, 214 N.E. 2d 114, 120 (Ohio Ct. App. 1966)).

137. Wilkins, supra note 19 , at 1168 . First, "to initiate an investigatory seizure, a police officer must have reasonable suspicion that the person being stopped 'ha[s] engaged, or [is] about to engage, in criminal activity." Id. (quoting Arizona v. Johnson, 555 U.S. 323 , 332 (2009)). Second, to search the individual, a police officer must have a reasonable suspicion that "he is dealing with an armed and dangerous individual." Id. at 1169 (quoting Terry v. Ohio, 392 U.S. 1, 27 (1968)).

138. See Terry, 392 U.S. at 30.

139. Id. at 24; see also Bellin, supra note 19 , at 30 .

140. See Terry, 392 U.S. at 26-31. "[I]f the frisk is justified in order to protect the officer during an encounter with a citizen, the officer must first have constitutional grounds to insist on an encounter, to make a forcible stop. ... [The person addressed] certainly need not submit to a frisk for the questioner's protection." Id. at 33 (Harlan, J., concurring); United States v. Gray, 213 F.3d 998, 1000-01 (8th Cir. 2000) (finding protective frisk violated the Fourth Amendment because officers had no reasonable suspicion that the individual was engaged in criminal activity); United States v. Burton, 228 F.3d 524, 527 (4th Cir. 2000) (holding that an officer may not 
Arizona courts have reaffirmed this distinct, two-pronged analysis under Terry, as well as the limited scope of a protective frisk:

"Terry allows a frisk only if two conditions are met: officers must reasonably suspect both that criminal activity is afoot and that the suspect is armed and dangerous." "141 "Although a frisk is less intrusive than a full-body search, the Fourth Amendment prohibits any search of an individual unless the police have a reasonable belief" that the two Terry prongs have been met. ${ }^{142}$ A Terry "pat-down search" allows the police to "pat[] down a suspect's outer clothing" in a manner "limited to that which is necessary for the discovery of weapons which might be used to harm the office or others nearby." 143

Notably, Arizona courts have also emphasized the constitutional requirement that officers develop reasonable suspicion of criminal activity prior to conducting a frisk, even if the officer feels endangered by an armed individual's presence. For example, in State v. Serna, the Arizona Supreme Court reversed the lower courts and invalidated a frisk of an individual who was standing in the middle of the street at night. ${ }^{144}$ Although the officer observed a "bulge," the court emphasized the lack of a predicate to justify the search: "facts sufficient to establish a reasonable suspicion of criminal activity." 145

Despite Arizona courts' respect for the distinct two-pronged analysis under Terry, the "reasonable suspicion" standard under either prong remains low in Arizona. ${ }^{146}$ An officer does not need probable cause to stop an individual. ${ }^{147}$ Indeed, reasonable suspicion may be demonstrated through an evidentiary showing that is "considerably less than a preponderance of the evidence." 148 While the stop must "be based on specific [and] articulable

conduct a protective search to allay a reasonable fear that a suspect is armed without first having a reasonable suspicion to support an investigatory stop).

141. State v. Serna, 331 P.3d 405, 410 (Ariz. 2014).

142. State v. Primous, 394 P.3d 646, 648 (Ariz. 2017).

143. State v. Valle, 996 P.2d 125, 128 (Ariz. Ct. App. 2000) (quoting Minnesota v. Dickerson, 508 U.S. 366, 373, 375-76 (1993)).

144. 331 P.3d at $406-07$.

145. Id. at 411 .

146. Id. (observing that "a reasonable suspicion of criminal activity [is] a low standard, readily established in many search settings").

147. Id.; State v. Evans, 332 P.3d 61, 63-64 (Ariz. Ct. App. 2014) (“Although an officer's reliance on a mere 'hunch' is insufficient to justify a stop, the likelihood of criminal activity need not rise to the level required for probable cause." (quoting United States v. Arvizu, 534 U.S. 266, $274(2002)))$.

148. State v. Ramsey, 224 P.3d 977, 981 (Ariz. Ct. App. 2010) (citing United States v. Sokolow, 490 U.S. 1, 7 (1989)). 
facts," ${ }^{149}$ Arizona courts have repeatedly observed that they will consider the "officer's relevant knowledge, experience, and training," 150 and will not "judge the dangers [facing an officer] '[w]ith the benefit of hindsight and calm deliberation,' but from the 'perspective of a reasonable officer on the scene." 151 Courts consider "the totality of the circumstances- the whole picture," 152 and allow officers to draw "rational inferences from th[e] facts," 153 including presence in a "high crime area" 154 or a "bulge" in an individual's pocket. ${ }^{155}$

\section{B. Lawful Carry and Unlawful Stops}

In the fifty years since Terry was decided in 1968, the United States Supreme Court has authorized a near-linear expansion of the permissible scope of the stop and frisk practice. While Terry involved an on-the-street stop of a would-be robber casing an establishment with a gun bulging from his coat ${ }^{156}$ since then the Court has upheld an officer's ability to frisk individuals stopped for minor traffic violations who are suspected of carrying weapons, ${ }^{157}$ search car compartments within "the lunge area" of the stopped individual, ${ }^{158}$ arrest suspects for refusing to affirmatively identify themselves during a Terry stop, ${ }^{159}$ and initiate a stop based on a mistake of law. ${ }^{160}$

149. Id.

150. State v. Sweeney, 227 P.3d 868, 873 (Ariz. Ct. App. 2010).

151. State v. Serna, 307 P.3d 82, 87 (Ariz. Ct. App. 2013) (quoting Ryburn v. Huff, 565 U.S. 469, 477 (2012)), vacated and rev'd, 331 P.3d 405 (Ariz. 2014).

152. State v. Ruiz, 372 P.3d 323, 326 (Ariz. Ct. App. 2016).

153. State v. Jarzab, 599 P.2d 761, 763 (Ariz. 1979).

154. Ramsey, 224 P.3d at 982.

155. State v. Primous, 394 P.3d 646, 648 (Ariz. 2017).

156. Terry v. Ohio, 392 U.S. 1, 5-7 (1968).

157. Arizona v. Johnson, 555 U.S. 323, 330-31 (2009) ("Most traffic stops . . resemble, in duration and atmosphere, the kind of brief detention authorized in Terry ... . [T]raffic stops are especially fraught with danger to police officers." (citations and quotations omitted)).

158. Michigan v. Long, 463 U.S. 1032, 1049 (1983) (holding that the principles of Terry "compel our conclusion that the search of the passenger compartment of an automobile... is permissible if the police officer possesses a reasonable belief . . . that the suspect is dangerous and the suspect may gain immediate control of weapons"); United States v. Morris, 1996 U.S. App. LEXIS 45162, at *4 (5th Cir. 1996) (citing Michigan v. Long to uphold officer's protective search of "the 'lunge area" of a suspect's car for weapons).

159. Hiibel v. Sixth Judicial Dist. Ct. of Nev., 542 U.S. 177, 188 (2004) ("[A]n officer may not arrest a suspect for failure to identify himself if the request for identification is not reasonably related to the circumstances justifying the stop.").

160. See Heien v. North Carolina, 135 S. Ct. 530, 536 (2014) (observing that the "reasonable suspicion" standard allows for officers to make reasonable mistakes of fact regarding criminality 
But in Arizona, the reasonableness calculation underlying current stop and frisk jurisprudence requires reexamination for armed individuals in public. To initiate a stop, an officer must have "reasonable suspicion supported by articulable facts that criminal activity "may be afoot." 161 But gun possession alone no longer reasonably indicates unlawful activity in Arizona, despite the low "reasonableness" standard articulated in Terry. ${ }^{162}$ The state's "increasingly permissive gun-possession laws erode the assumption that public handgun possession is unlawful." ${ }^{163}$ When Arizona "elect[ed] to legalize the public carry of firearms, ... the Fourth Amendment equation change[d], and public possession of a gun is no longer 'suspicious' in a way that would authorize a Terry stop." ${ }^{164}$ Therefore, reasonable suspicion to initiate a Terry stop requires more than the mere presence of a firearm. ${ }^{165}$

Neither can an officer stop an armed individual solely for protection purposes under Terry's second prong. ${ }^{166}$ While Terry authorizes protective frisks for the safety of the officer and the nearby public, such a frisk requires as a predicate that the individual is lawfully stopped on suspicion of criminal

or dangerousness, and finding that "[t]here is no reason ... why this same result should [not] be acceptable ... when reached by way of a similarly reasonable mistake of law").

161. In re Ilono H., 113 P.3d 696, 697 (Ariz. Ct. App. 2005).

162. Bellin, supra note 19, at 26, 41 ("[C]ourts will be hard-pressed to accept, as constituting 'reasonable suspicion' of a crime, an observation of an increasingly common [and lawful] activity ....").

163. Id. at 25 ("Consequently, the Fourth Amendment authority flowing from that assumption must be reevaluated.").

164. United States v. Robinson, 846 F.3d 694, 708 (4th Cir. 2017) (Harris, J., dissenting) ("'Permitting such a justification' for a Terry stop ... 'would eviscerate Fourth Amendment protections for lawfully armed individuals in those states." (quoting United States v. Black, 707 F.3d 531, 540 (4th Cir. 2013))).

165. See Florida v. J.L., 529 U.S. 266, 272 (2000) (finding unconstitutional search of individual based solely on tip that he was carrying a firearm and declining to adopt a "firearm exception" to Terry stops); see also Pinner v. State, 74 N.E.3d 226, 232 (Ind. 2017) (citing J.L. and finding inadequate a "tip provided by the taxi driver [that] made no 'assertion of illegality,' [but] rather ... merely had a 'tendency to identify a determinate person' who was in possession of a handgun").

166. See, e.g., United States v. Massenburg, 654 F.3d 480, 485 (4th Cir. 2011) (noting that reasonable suspicion is "required prior to a frisk when the officer's initial encounter with the citizen is voluntary"); United States v. Burton, 228 F.3d 524, 527 (4th Cir. 2000) (stating that a "police officer may elevate a police-citizen encounter into an investigatory detention only if the officer has a "reasonable suspicion supported by articulable facts that criminal activity "may be afoot"" (quoting United States v. Sokolow, 490 U.S. 1, 7 (1989))); United States v. Ubiles, 224 F.3d 213, 214 (3d Cir. 2000) (finding stop and search based on possession of gun unjustified because carrying firearms was not illegal and thus could not alone provide reasonable suspicion of criminal activity); United States v. Gray, 213 F.3d 998, 1000-01 (8th Cir. 2000) (finding protective frisk violated Fourth Amendment because officers had no reasonable suspicion that a man who willingly stopped and answered questions was engaged in criminal activity). 
activity. ${ }^{167}$ Arizona courts have long held that "an officer's right to conduct a pat-down search should be predicated on the officer's right to initiate an investigative stop in the first instance." ${ }^{68}$ Indeed, to hold otherwise would be to subject all lawfully armed and law abiding Arizonans to random searches of their person and vehicles for merely exercising their statutory rights to carry weapons. This approach would untether the Fourth Amendment from its reasonable suspicion foundations and eviscerate Fourth Amendment protections for public weapons carriers.

\section{Arizona's "Duty to Inform" Law}

In an unrestricted or "constitutional carry" jurisdiction like Arizona, where no state limits exist on the right to carry firearms in public, officers cannot demonstrate reasonable suspicion of criminality based solely on firearm possession. ${ }^{169}$ But what if the officer suspects the armed individual is in possession of the weapon illegally, either as an underage Arizonan or a convicted felon? Without any other indicia of criminality giving rise to a reasonable suspicion that some non-weapons possession offense was being committed, the officer likely would have to resort to asking the individual for proof of his authority to possess the weapon. But without reasonable suspicion to initiate a stop, what right under the first Terry prong would an officer have to demand such information? ${ }^{170}$

Although Arizona police officers may no longer reasonably rely on an individual's weapons possession to suspect criminal activity and initiate an investigative detention, it often remains important from a protection standpoint for officers to know whether someone possesses a weapon. For

167. Terry v. Ohio, 392 U.S. 1, 32 (1968) (Harlan, J., concurring) ("[I]f the frisk is justified in order to protect the officer during an encounter with a citizen, the officer must first have constitutional grounds to insist on an encounter ....").

168. In re Ilono H., 113 P.3d 696, 700 (Ariz. Ct. App. 2005); see also Gomez v. United States, 597 A.2d 884, 890-91 (D.C. 1991) (noting that, without reasonable suspicion, police could not justify a frisk based on officer safety concerns alone); Commonwealth v. Narcisse, 927 N.E.2d 439, 445 (Mass. 2010) ("[P]olice officers may not escalate a consensual encounter into a protective frisk absent reasonable suspicion that an individual has committed, is committing, or is about to commit a criminal offense and is armed and dangerous."); Speten v. State, 185 P.3d 25, 33 (Wyo. 2008) ("[T] here is neither a 'freestanding' right to search based solely upon officer safety concerns, nor is there a 'freestanding' right to search based solely upon reasonable suspicion of the presence of weapons ....").

169. United States v. King, 990 F.2d 1552, 1559 (10th Cir. 1993) (finding that to allow stops of all armed persons in a permissive concealed carry jurisdiction "would effectively eliminate Fourth Amendment protections for lawfully armed persons").

170. See Bellin, supra note 19, at 38-39 (discussing constitutional problems with "gunlicense inquiry" statutes). 
example, an officer at a crowded and heated protest rally would certainly want to know whether one of the more agitated participants was armed. Moreover, an officer would be keenly interested in knowing whether a convicted felon or a minor-both prohibited firearms possessors under Arizona and federal law-were in possession of a firearm. But without independent reasonable suspicion of criminality to detain and question the individuals, how can an officer gain this information?

Arizona has attempted to solve this issue by giving law enforcement greater authority to investigate the presence and lawfulness of public weapons possession. ${ }^{171}$ A.R.S. section 13-3102 authorizes police officers to inquire whether an individual "is carrying a concealed deadly weapon," whether or not the officer has any suspicion that the individual has committed or is committing a crime ${ }^{172}$ In fact, "failing to accurately answer the officer" is itself a crime. ${ }^{173} \mathrm{~A}$ corollary to this provision requires Arizona concealed carry permit holders to carry their permits with them and present them to officers upon request. ${ }^{174}$

In essence, Arizona has created a form of weapons-license inquiry mechanism whereby, as a condition of exercising concealed carry rights, possessors agree to disclose the presence of weapons (and permit licenses) to police officers upon request. ${ }^{175}$ Several other states have enacted similar "gun-license inquiry" laws, though most of these sister statutes go further than the Arizona law in that they require public gun possessors to affirmatively disclose the presence of firearms (and provide the relevant permit, where necessary) as soon as they are approached by a peace officer. ${ }^{176}$ In contrast, Arizona only requires such disclosure if specifically asked by an officer. ${ }^{177}$

171. See, e.g., id. at 29 (discussing legislation in Georgia authorizing police officers to ask for documents confirming lawfulness of gun possession).

172. ARIz. ReV. StAT. ANN. § 13-3102(A)(1)(b) (2019).

173. Id.

174. Id. $\S 13-3112(\mathrm{~A})$.

175. Bellin, supra note 19 , at $38-39$.

176. See VA. CODE ANN. $\$ 18.2-308.07$ (A) (2019) (requiring permit information to be entered into a database "so that the permit's existence and current status will be made known to law-enforcement personnel accessing the Network for investigative purposes."); WIS. STAT. $\S 175.60(12)(b)$ (2019) (providing for database that can be queried "to confirm that a license ... is valid" and when "an individual is carrying a concealed weapon and claims to hold a valid license ... but does not have his or her license document or certification card, to confirm that the individual holds a valid license or certification card"). But see GA. CODE ANN. § 16-11-129(k) (2019) (prohibiting "multijurisdictional data base of information regarding persons issued weapons carry licenses").

177. ARIz. Rev. Stat. AnN. § 13-3112(A)-(C) (2019) (requiring licensees "to carry the permit" and "present the permit for inspection to any law enforcement officer on request"); see 
This approach makes sense as a matter of policy, as it allows officers to determine whether a safety issue exists in a sensitive location, such as a crowded mall, and respond accordingly. If an officer identifies an armed individual in a sensitive location, he can then inquire further about the individual's motives and ability to lawfully possess the weapon. ${ }^{178}$

But this sound policy does not solve the constitutional issue surrounding stops of lawful weapons carriers. Rather, this duty to inform law raises serious constitutional questions in its own right. Under a traditional Terry analysis, an officer must have reasonable suspicion of criminal activity to initiate an investigative seizure. ${ }^{179}$ While an officer can ask an armed individual any question he wants - including whether he has a concealed carry permit - that individual has every constitutional right not to answer unless that individual has been constitutionally "seized." That seizure is only permissible if the officer has individualized reasonable suspicion of criminal activity. In other words, an arrest for failure to present a concealed carry permit can only be upheld as long as the stop was "justified at its inception" and the request for information "has an immediate relation to the purpose, rationale, and practical demands of a Terry stop." 180

Thus, under existing precedent, these weapons-possession inquiries can only survive constitutional scrutiny if the officer had some independent, lawful reason to initiate the Terry stop. If the police cannot constitutionally require weapons carriers to disclose their carriage of weapons, officers cannot consider a failure to respond to a voluntary possession inquiry as a basis for reasonable suspicion. ${ }^{181}$

also D.C. CODE $\S 7-2502.08$ (c) (2019) (same); TEX. Gov'T CODE ANN. § 411.205 (West 2019) (same); VA. CODE ANN. $§ 18.2-308.01$ (A) (2019) (same); Wis. STAT. $\$ 175.60(2 \mathrm{~g}$ )(b)-(c) (2019) (same); $c f$. N.Y.C., N.Y., Rules OF THE CiTY OF N.Y. tit. 38, § 5-22(6) (2019) ("The licensee shall be in possession of her/his license at all times while carrying, transporting, possessing at residence, business, or authorized small arms range/shooting club, the handgun(s) indicated on said license.").

178. See, e.g., United States v. Orman, 486 F.3d 1170, 1171, 1175 (9th Cir. 2007).

179. See id. ("The framework's constitutionality depends on whether police can compel gun carriers to stop what they are doing and produce a firearm license.").

180. Hiibel v. Sixth Judicial Dist. Ct. of Nev., 542 U.S. 177, 185, 188 (2004); see also Bellin, supra note 19 , at 40 ("Gun-license-inquiry provisions purport to authorize police to request a license prior to the officer's development of 'reasonable suspicion' to suspect a gun carrier of any offense. The proper analogy would be to a police officer pulling over a driver who had not violated any traffic law and asking the driver to produce a license ....").

181. See Delaware v. Prouse, 440 U.S. 648, 663 (1979) (holding that without "at least articulable and reasonable suspicion that a motorist is unlicensed ... stopping an automobile and detaining the driver in order to check his driver's license ... [is] unreasonable under the Fourth Amendment"); Bellin, supra note 19, at 39-40. 
Thus, Arizona's duty to inform law only has teeth to the extent that individuals consent to the officer's questioning. But while a police officer is free to approach individuals and ask questions absent reasonable suspicion, individuals are free to refuse to cooperate. ${ }^{182}$ But in a "weapon possession inquiry" state like Arizona, would not refusal to cooperate indicate unlawful weapons possession as a matter of logic, at least where the officer knows the individual is armed? Such a scenario seems likely in a gun-license inquiry regime, but it would also turn Fourth Amendment jurisprudence on its head. "[A] refusal to cooperate, without more, does not furnish the minimal level of objective justification needed for a detention or seizure." ${ }^{183}$ But in a jurisdiction where every law-abiding gun carrier has consented to cooperate with authorities, it would appear that an individual's refusal to cooperate, without more, would create reasonable suspicion of unlawful weapons possession. ${ }^{184}$

These duty-to-inform laws seem particularly ill-suited in "constitutional carry" states like Arizona, where virtually no restrictions exist on the right to carry concealed guns and knives. Even if an individual answers "yes" to an innocent officer's inquiry as part of a consensual encounter, what pertinent information does that answer reasonably furnish in a state where concealed possession without a permit is legal? Unlike "may issue" and "shall issue" states requiring concealed carry permit applicants to contract with the state to furnish their permits to officer's upon request to confirm the lawfulness of their possession, Arizonans' lawfulness to possess generates from their presence in the state.

\section{DOES ARMED EQUAL DANGEROUS IN ARIZONA?}

As the previous section illustrates, when the Arizona legislature "decided its citizens may be entrusted with firearms on public streets," Arizona police

182. See Florida v. Bostick, 501 U.S. 429, 437 (1991) ("We have consistently held that a refusal to cooperate, without more, does not furnish the minimal level of objective justification needed for a detention or seizure.").

183. Id.; see also Terry v. Ohio, 392 U.S. 1, 34 (1968) (White, J., concurring) (" $[T]$ he person stopped is not obliged to answer, answers may not be compelled, and refusal to answer furnishes no basis for an arrest, although it may alert the officer to the need for continued observation.").

184. Concealed permit carriers are free to contract away certain Fourth Amendment rights. Zap v. United States, 328 U.S. 624, 628 (1946) (affirming surrender of Fourth Amendment rights); Jason S. Thaler, Public Housing Consent Clauses: Unconstitutional Condition or Constitutional Necessity?, 63 FordHAM L. REV. 1777, 1794-95 ("The Supreme Court has affirmed the view that a person can surrender constitutional rights by contract. Individuals may voluntarily contract away Fourth Amendment rights."). But their decision to do so should not strip away the robust Fourth Amendment protections of those who chose not to do so. 
lost the authority initiate Terry stops based on nothing more than suspicion of weapons possession. ${ }^{185}$ But once a lawful Terry stop has been initiated, what level of reasonable suspicion is necessary to initiate a frisk? Must the officer determine through "specific and articulable facts" that the suspect is not only armed, but also dangerous? ${ }^{186}$ Can the officer simply rely on the actual or suspected presence of a weapon to conclude that the individual is "armed, and thus dangerous?" 187 And does the analysis change whether the weapon is a firearm or a knife?

The following section considers the contradictory answers provided to these questions by the Ninth Circuit, the Arizona Supreme Court, and other jurisdictions.

\section{A. Ninth Circuit: United States v. Orman ${ }^{188}$}

On August 20, 2004, at approximately 3:45 p.m., Dale Orman and his wife entered the Paradise Valley Mall in Phoenix. An employee of Arizona Public Service, a local utility company, observed Orman placing a handgun in his boot before entering the mall and reported it to mall personnel. ${ }^{189}$ Mall security contacted Officer John Ferragamo of the Phoenix Police Department, who shortly thereafter found Orman in the mall based on the description provided ${ }^{190}$ Ferragamo approached Orman and asked whether he was carrying a handgun, and Orman admitted that he was. ${ }^{191}$ Ferragamo immediately retrieved the handgun and then directed Orman to the mall security office, where he was later arrested for being a felon in possession of a firearm. ${ }^{192}$

Orman challenged the search as unconstitutional under the Fourth Amendment, pursuant to Terry's two-pronged approach that reasonable

185. Northrup v. City of Toledo Police Dep't, 785 F.3d 1128, 1131-33 (6th Cir. 2015).

186. United States v. Robinson, 846 F.3d 694, 709 (4th Cir. 2017) (Harris, J., dissenting) ("[T]he Supreme Court for decades has adhered to the conjunctive 'armed and dangerous' formulation, giving no indication that 'dangerous' may be read out of the equation as an expendable redundancy.").

187. Id. at 700 (observing that the Court in Terry concluded that the suspect was "armed and thus presented a threat to the officer's safety").

188. Ninth Circuit decisions clearly have binding effect on federal decisions reached in Arizona. Moreover, while "decisions of the Ninth Circuit ... are not binding," they are often relied upon as "persuasive authority to which Arizona courts may look." Phx. Newspapers, Inc. v. Reinstein, 381 P.3d 236, 243 (Ariz. Ct. App. 2016).

189. See United States v. Orman, 486 F.3d 1170, 1171 (9th Cir. 2007).

190. See id. at 1171-72.

191. See id. at 1172 .

192. See id. 
suspicion of criminal activity must be present before a protective search can be conducted. ${ }^{193}$ In surprisingly broad language, the Ninth Circuit rejected the argument, finding that the seizure was justified "for safety purposes" even if the officer lacked reasonable suspicion that criminal activity was afoot. ${ }^{194}$ Even though Officer Ferragamo readily admitted he lacked reasonable suspicion of criminal activity and was only concerned that Orman "might have a gun" in a state authorizing permitless concealed carry, the court upheld the search, explaing that "reasonable suspicion that [a person is] carrying a gun . . . is all that is required for a protective search under Terry." 195

The court justified its decision by emphasizing both the purpose of a Terry frisk and the unique circumstances of the case at hand. The court observed that:

Terry explained that a search for weapons is justified by the "immediate interest of the police officer in taking steps to assure himself that the person with whom he is dealing is not armed with a weapon that could unexpectedly and fatally be used against him". .. . [I]t would be "clearly unreasonable to deny the officer the power to take necessary measures to determine whether the person is in fact carrying a weapon and to neutralize the threat of physical harm. $" 196$

On its face, this reasoning appears to eliminate entirely the first prong of Terry. Officer Ferragamo did not need reasonable suspicion that Orman was engaged in criminal activity to stop and frisk him because Ferragamo reasonably suspected Orman was armed, which "is all that is required." 197 This reasoning would appear to render Terry's longstanding two-pronged test into a disjunctive inquiry: an officer can stop someone if reasonable suspicion exists that criminal activity is afoot, or an officer can frisk someone (which necessarily entails a "stop") if reasonable suspicion exists that the person is armed.

The court also attempted to justify its troubling result by emphasizing that Officer Ferragamo's quick retrieval of the weapon was far less "intrusive" than a traditional frisk pat-down, and that the gun was readily accessible to Orman as Ferragamo stood "only inches" away. ${ }^{198}$ To the court, this "record

193. See id. at $1172-73$.

194. Id. at 1176.

195. Id; see also id. at 1173 ("Terry did not cabin the use of officer safety patdowns to lawful investigatory detentions.").

196. Id. at 1176 (quoting Terry v. Ohio, 392 U.S. 1, 23-24 (1968)).

197. Id.

198. Id. 
evidence[d] the tempered act of a policeman who in the course of an investigation had to make a quick decision as to how to protect himself and others from possible danger, and took limited steps to do so." ${ }^{199}$ But a search is a search, and the forced disarmament of an armed individual undoubtedly qualifies. Under Terry and well-settled Fourth Amendment precedent, such frisks, even if less invasive than other frisks, requires the predicate of reasonable suspicion of criminal activity. ${ }^{200}$

In its truncated analysis, the Ninth Circuit failed to discuss whether Orman was "presently dangerous" when frisked by Ferragamo. ${ }^{201}$ Terry states that an officer can frisk an individual only if reasonable suspicion exists that the suspect is armed and presently dangerous, suggesting that the possession of a weapon alone may not justify a protective frisk. ${ }^{202}$ The court's broad language that "carrying a gun" is all that is required to justify a search seems to create a categorical approach, at least as to firearms: if you are in possession of a firearm, you are necessarily and presently dangerous. ${ }^{203}$

One final aspect of the case may explain the logic behind the court's puzzling decision, at least partially. The encounter preceding the frisk was consensual; thus, Officer Ferragamo did not need reasonable suspicion of criminal activity to initiate the questioning of Orman. ${ }^{204}$ But whether an officer needs suspicion of criminal activity to start questioning someone is quite different from whether the officer needs suspicion that the individual is "armed and presently dangerous" to initiate a frisk. The Arizona Supreme Court directly addressed this issue in 2014 .

\section{B. Arizona State Courts: State v. Serna}

At approximately 10:00 p.m., two officers patrolling a "gang neighborhood" in Phoenix observed Johnathon Serna and a woman standing in the middle of the street. ${ }^{205}$ When the officers turned their patrol car towards

199. Id. at 1177 .

200. See supra notes 148-49 and accompanying text. The court's reliance on Pennsylvania v. Mimms on this point is misplaced. See Orman, 486 F.3d at 1176-77. The court notes that the Supreme Court upheld the frisk of a suspect driving with an expired plate after the officer noticed a bulge under his jacket, explaining that "any man of reasonable caution would likely have conducted the pat down." Id. But unlike here, reasonable suspicion (indeed, likely probable cause) of criminal conduct existed to justify the frisk, because public gun possession was illegal in Pennsylvania at the time.

201. Orman, 486 F.3d at $1176-77$.

202. Terry v. Ohio, 392 U.S. 1, 28 (1968).

203. Orman, 486 F.3d at 1176.

204. See id.

205. State v. Serna, 331 P.3d 405, 406 (Ariz. 2014). 
the pair they separated, and the officers pulled their car up next to Serna. ${ }^{206}$ When the Officer Richey called to Serna, he walked over to the patrol car and was "very cooperative and polite" during the brief conversation ${ }^{207}$ Officer Richey then noticed a bulge on Serna's waistband and asked if he was carrying firearms. ${ }^{208}$ Serna replied that he had a gun, at which point both officers ordered Serna to put his hands on his head while Officer Richey removed the gun from Serna's person. ${ }^{209}$ When Serna later admitted he had a felony conviction, the officers arrested him as a prohibited possessor of a firearm. ${ }^{210}$

Serna moved to suppress the firearm as illegally obtained evidence under the Fourth Amendment. ${ }^{211}$ When the case reached the Arizona Supreme Court in 2014, two critical issues faced the court. First, the Court considered "[w]hether an officer must possess reasonable suspicion that criminal activity is afoot in order to frisk an individual." 212 Second, it explored whether, even if an officer has no reasonable suspicion of criminal activity, the mere fact that an individual was armed was sufficient under Terry's second prong to initiate a protective frisk. ${ }^{213}$

As to the first issue, the Court emphatically (and correctly) said yes, reaffirming the distinct, conjunctive two-pronged approach in Terry. ${ }^{214}$ Relying on Adams v. Williams ${ }^{215}$ and Arizona v. Johnson, ${ }^{216}$ the Court concluded that two independent threshold criteria must be met to justify a protective frisk: "First, the investigatory stop must be lawful" by virtue of the officer's reasonable suspicion of criminal activity; "Second, to proceed from

206. Id. at 407 .

207. Id.

208. Id.

209. Id.

210. Id.

211. Id.

212. Id. In articulating the issue, the Court succinctly summarized the open Terry question before it:

In Terry, the Court stated that an officer is justified in frisking individuals for weapons if the officer can reasonably conclude "[1] that criminal activity may be afoot and [2] that the persons with whom he is dealing may be armed and presently dangerous." The question before us now is whether a frisk must be supported by both of these conditions, or whether satisfying just one will suffice.

Id. at 408 .

213. Id. at 409 .

214. See id. at 408 .

215. 407 U.S. 143 (1972).

216. 555 U.S. $323(2009)$. 
a stop to a frisk, the police officer must reasonably suspect that the person stopped is armed and dangerous." 217 The Court relied heavily on the concurrence of Justice Harlan in Terry explaining why independent reasonable suspicion was required for a protective frisk:

$[I] f$ the frisk is justified in order to protect the officer during an encounter with a citizen, the officer must first have constitutional grounds to insist on an encounter, to make a forcible stop. Any person, including a policeman, is at liberty to avoid a person he considers dangerous. If and when a policeman has a right instead to disarm such a person for his own protection, he must first have a right not to avoid him but to be in his presence. That right must be more than the liberty (again, possessed by every citizen) to address questions to other persons, for ordinarily the person addressed has an equal right to ignore his interrogator and walk away; he certainly need not submit to a frisk for the questioner's protection. I would make it perfectly clear that the right to frisk ... depends on the reasonableness of a forcible stop to investigate a suspected crime. ${ }^{218}$

As to the second issue, whether an armed individual is per se dangerous for purposes of a Terry frisk, the Court answered no. ${ }^{219}$ In doing so, it "disagree[d] with the Ninth Circuit's determination [in Orman] that mere knowledge or suspicion that a person is carrying a firearm satisfies the second prong of Terry, which itself involves a dual inquiry; it requires that a suspect be "armed and presently dangerous." 220 The Court found that, "[i]n a state such as Arizona that freely permits citizens to carry weapons, both visible and concealed, the mere presence of a gun cannot provide reasonable and articulate suspicion that the gun carrier is presently dangerous." 221

This reasoning mirrors that of courts in the Sixth ${ }^{222}$ and Seventh Circuits, ${ }^{223}$ as well as the original Fourth Circuit panel decision ${ }^{224}$ and a vigorous en banc

217. Serna, 331 P.3d at 408.

218. Id. at 408-09 (quoting Terry v. Ohio, 392 U.S. 1, 32-33 (1968) (Harlan, J., concurring)).

219. Id. at 410 .

220. Id.

221. Id.

222. See Northrup v. City of Toledo Police Dep't, 785 F.3d 1128, 1132 (6th Cir. 2015) (holding that "[c]learly established law require[s] [officers] to point to evidence" that suspects are both "armed and dangerous").

223. See United States v. Williams, 731 F.3d 678, 693-94 (7th Cir. 2013) (Hamilton, J., concurring in part and concurring in the judgment).

224. See United States v. Robinson, 814 F.3d 201, 206 n.2 (4th Cir. 2016) ("The Supreme Court for decades has adhered to its conjunctive 'armed and dangerous' formulation, giving no indication that 'dangerous' may be read out of the equation as an expendable redundancy."). 
dissent in United States v. Robinson. ${ }^{225}$ A significant flaw in this reasoning exists, however, in that it assumes all lawful activity is necessarily not dangerous. By claiming that Arizona's permission for citizens to carry weapons negates the dangerousness of those citizens, the Serna Court ignores the inherent dangerousness of weapons-especially firearms - even when handled properly by law abiding individuals. ${ }^{226}$ While the Court correctly observed that the broad permission granted Arizonans to lawfully possess weapons negates the automatic conclusion that such possession is indicative of unlawful behavior, it fails to address the fact that lawful possession can nonetheless be dangerous.

Of course, many lawful activities are dangerous. Driving a car is among the most dangerous activities widely engaged in by a majority of citizens, but that does not give officers the right to stop all drivers - only the reckless ones. Or put differently, a firearm in the hands of a criminal intent on committing armed robbery certainly poses a greater danger than a firearm in the hands of a law-abiding citizen holstering the weapon for defensive protection. But that is precisely the point. An officer faced with the decision whether to frisk an armed individual under Terry's second prong has already reasonably determined that the individual is engaged in criminal activity. That determination alone raises the risk that the armed individual is dangerous.

For its part, the Serna Court did acknowledge this possibility, hypothesizing that, "[h]ad reasonable suspicion of criminal activity existed before the encounter or developed during the encounter, given that Serna was armed, the officer may have had grounds to frisk Serna." 227 But because the encounter between Serna and the officer was consensual, no right existed to

225. See United States v. Robinson, 846 F.3d 694, 711 (4th Cir. 2017) (Harris, J., dissenting) ("[B]y equating 'armed' with 'dangerous' even in states where the carrying of guns is widely permitted, the majority's rule has the effect of depriving countless law-abiding citizens of what otherwise would be their Fourth Amendment and other constitutional rights.").

226. See Robinson, 846 F.3d at 705 ("[I]ndividuals who choose to carry firearms-are inherently dangerous."); In re Deep Vein Thrombosis, 356 F. Supp. 2d 1055, 1066 (N.D. Cal. 2005) (noting the affirmative duties of care imposed on "manufacturers of firearms, an inherently dangerous instrumentality"); Smith v. Brooks, 545 S.E.2d 135, 137 (Ga. Ct. App. 2001) (observing that "a higher standard of care" applies because "a loaded firearm . . . amounted to an inherently dangerous instrumentality"). Courts in criminal cases have long referred to firearms as "inherently dangerous instrumentalit[ies]" for purposes of inferring intent. See, e.g., State v. Widner, 431 N.E.2d 1025, 1028 (Ohio 1982) (finding that a jury can infer intent to kill when a firearm is used, "[g]iven the fact that a firearm is an inherently dangerous instrumentality, the use of which is reasonably likely to produce death"); State v. Clark, No. 89371, 2008 WL 803034, at *3 (Ohio Ct. App. Mar. 27, 2008) ("A jury can infer intent to kill by the defendant's use of a firearm, an inherently dangerous instrumentality ....").

227. State v. Serna, 331 P.3d 405, 410 (Ariz. 2014). 
conduct a frisk absent the development of reasonable suspicion to initiate an involuntarily stop. ${ }^{228}$

This aspect of Serna reflects the limits of its holding: read narrowly, the case only applies to consensual encounters and does not answer the more difficult question of whether officers can automatically frisk and disarm weapons carriers in Arizona who have been lawfully stopped under Terry. ${ }^{229}$ On that question, the Court offered conflicting signals. On the one hand, the Court seemed to imply that an officer needed only to develop reasonable suspicion that the lawfully stopped individual was armed. ${ }^{230}$ But elsewhere in its opinion, the Court emphasizes the two-pronged inquiry contained within Terry's second prong: that an individual must not only be armed but also dangerous before an officer can frisk him. Whether and to what extent weapons possession could lead to a per se finding of dangerous - for example, when an individual possesses a high-capacity AR-15 in a crowd versus when an individual possesses a switchblade on an empty street - was left unanswered by the Court.

\section{What About Nonconsensual Encounters?}

Orman and Serna reached radically different conclusions on remarkably similar facts, only increasing confusion for Arizona officers deciding whether and when to frisk an armed individual. These cases suffer from another limitation: they both involved consensual encounters and did not directly address when an officer can frisk a lawfully and involuntarily stopped armed Arizonan. ${ }^{231}$ Put another way, is a lawfully stopped armed individual automatically dangerous for purposes of Terry's second prong, or must an officer make an independent determination that the suspect is not only armed, but also dangerous?

Courts in other jurisdictions have split on the issue. For example, in United States v. Robinson, ${ }^{232}$ the Fourth Circuit held that any individual who the police suspect possesses a firearm becomes a dangerous individual per se for

228. See id. ("To conclude otherwise would potentially subject countless law-abiding persons to patdowns solely for exercising their right to carry a firearm.").

229. See id. at 411 ("Our holding governs only those circumstances in which the police wish to search a person with whom they are engaged in a consensual encounter.").

230. See id. at 410.

231. See id. at 411 ("Our holding governs only those circumstances in which the police wish to search a person with whom they are engaged in a consensual encounter.") (emphasis added); United States v. Orman, 486 F.3d 1170, 1177 (9th Cir. 2007) ("We hold that Officer Ferragamo's initial encounter with Orman was consensual ....") (emphasis added).

232. 846 F.3d 694 (4th Cir. 2017). 
Terry purposes. ${ }^{233}$ In contrast, in Northrup v. City of Toledo Police Department, ${ }^{234}$ the Sixth Circuit held that, "[c]learly established law require[s officers] to point to evidence" that suspects are both "armed and dangerous." 235 Only in Robinson did the court discuss the dangerousness of the firearm, but the court's holding ultimately rested on the risk the individual posed to the police. ${ }^{236}$

The "distinct approaches" of these courts to the firearms frisk question reflects a growing tension with how and to what degree of invasiveness an officer can police a heavily armed citizenry. ${ }^{237}$ On the one hand, the "categorical approach" would find that "reasonable suspicion that a suspect is armed is per se sufficient to conclude that the suspect is dangerous and to conduct a frisk." ${ }^{238}$ On the other hand, the "independent dangerousness approach ... permits a frisk only if the suspect is deemed to be dangerous based on factors other than mere weapons possession." 239

It is also worth noting that all of these cases, as well as Orman and Serna, involved firearms. ${ }^{240}$ What does this mean for Arizona's concealed knife possessors? Should knives be treated just like firearms, even though virtually any object, including a "wine bottle," can be made into a lethal weapon? ${ }^{241}$ Or should Arizona courts adopt a "modified categorical approach ... [a] firearms-only categorical approach" that authorizes automatic frisks of gun carriers but not for other weapons carriers? ${ }^{242}$ The following section attempts to answer some of these questions.

233. Id. at 704 ("[T] he officers reasonably believed that the person stopped "was armed and thus' dangerous."); cf. id. at 709 (Harris, J., dissenting) (explaining that "armed" and "dangerous" are two separate prongs of a conjunctive test).

234. 785 F.3d 1128 (6th Cir. 2015).

235. Id. at 1132 .

236. Robinson, 846 F.3d at 705 (emphasis added) (collecting cases observing the "inherently violent nature of firearms," and concluding that "lawfully-stopped individuals armed with firearms are categorically dangerous").

237. J. Richard Broughton, Danger at the Intersection of Second and Fourth, 54 IDAHO L. REV. 379, 390 (2018) (summarizing "three distinct approaches" emerging from Robinson).

238. Id. (quoting Robinson, 846 F.3d at 695-702).

239. Id.

240. Robinson, 846 F.3d at 695 (describing investigatory stop initiated "[a]fter receiving a tip that a man in a parking lot well known for drug-trafficking activity had just loaded a firearm"); Northrup, 785 F.3d at 1130 (recalling that the police encounter began after "[a] passing motorcyclist stopped to complain about [Mr. Northrup's] visible firearm"); United States v. Orman, 486 F.3d 1170, 1171 (9th Cir. 2007); State v. Serna, 331 P.3d 405, 407 (Ariz. 2014).

241. United States v. Daulton, 488 F.2d 524, 525 (5th Cir. 1973) ("[C]ourts have held that a wine bottle can be a dangerous weapon.").

242. Broughton, supra note 237 , at 390. 


\section{Policy Considerations for Guns and Knives}

When carefully scrutinized, neither the "categorical" approach nor the "independent dangerousness" approach pass muster as a matter of law or policy. Particularly in a "constitutional carry" state like Arizona, where the concealed carry of all types of weapons is legal and ubiquitous, a more carefully tailored approach is needed to balance the rights of Arizonans to remain armed in public with the obligation of Arizona law enforcement to protect and serve.

The categorical approach ignores the wide array of circumstances in which an individual can be "armed," particularly in a knife-friendly state like Arizona. Terry states that an officer can conduct a protective frisk of a lawfully stopped individual if the officer has "reason to believe that he is dealing with an armed and dangerous individual." 243 Clearly, then, a condition precedent to conducting a lawful frisk is the presence of a weapon. ${ }^{244}$ If the individual is not "armed" (or at least if the officer lacks reasonable suspicion that he is armed), then the circumstance do not justify a frisk. $^{245}$

But armed with what? As Justice Brennan noted in Wright v. New Jersey, numerous everyday objects turn into "weapons" when put to appropriate use:

A "weapon" could include a brick, a baseball bat, a hammer, a broken bottle, a fishing knife, barbed wire, a knitting needle, a sharpened pencil, a riding crop, a jagged can, rope, a screw driver, an ice pick, a tire iron, garden shears, a pitch fork, a shovel, a length of chain, a penknife, a fork, metal pipe, a stick, etc. The foregoing only illustrate the variety of lawful objects which are often innocently possessed without wrongful intent. ${ }^{246}$

With this admonition in mind, the categorical approach seems untenable. As Judge Wynn stated in his concurrence in Robinson, there is an "absurdity" to automatically collapsing the " armed and dangerous' test into a single inquiry-regardless of the type of 'weapon' with which the detainee is 'armed." ${ }^{247}$ The categorical approach would authorize invasive frisks based on a bright-line formula of forcible stop + weapon $=$ danger, even if the two inputs to that equation are seatbelt violation + sharpened pencil.

The "independent dangerousness" approach fares no better, however. ${ }^{248}$ While one might reasonably expect an officer to independently assess

243. Terry v. Ohio, 392 U.S. 1, 27 (1968); see Serna, 331 P.3d at 410.

244. See Serna, 331 P.3d at 410.

245. Id.

246. Wright v. New Jersey, 469 U.S. 1146, 1149 n.3 (1985) (Brennan, J., dissenting).

247. United States v. Robinson, 846 F.3d 694, 703 (4th Cir. 2017) (Wynn, J., concurring).

248. Id. at 709 (Harris, J., dissenting). 
whether a stopped suspect truly poses a danger with a pencil or a knitting needle, supporters of the independent dangerousness approach invariably invoke it with respect to the most inherently dangerous weapon of all: firearms. For example, in her Robinson dissent, Judge Harris "[n]ot only . . . reject[s] a categorical approach, particularly one aimed at guns, she also concludes that the proper Fourth Amendment approach is one that engages in an independent inquiry into whether the suspect - even one carrying a gunis dangerous." 249 According to Judge Harris, because "modern firearms law has granted substantially more legal protection to citizens as gun owners," officers "no longer may take for granted the same correlation between 'armed' and 'dangerous."

This reasoning fails for two reasons. First, while expanding gun rights may speak to the general law abidingness of gun owners generally, they do not confer special protection to gun owners who have been lawfully stopped on suspicion of criminal activity. Terry requires officers to have first developed reasonable suspicion that criminal activity is afoot before even reaching the question of whether or not to frisk. Those lawfully stopped suspects fairly lose the presumption of law abidingness. We should no longer take for granted the same correlation between "armed" and "dangerous" for the general Arizona population, but lawfully stopped Arizonans stand in a separate, more suspicion category.

Second, even if expanding gun rights laws force us to reexamine the correlation between an "armed individual" and a "dangerous individual," no law can change the inherent dangerousness of the firearm itself. Courts have repeatedly found that guns are uniquely and inherently dangerous. ${ }^{251}$ Federal sentencing guidelines treat firearms as "inherently dangerous instrumentalities." Police officer and military training manuals stress the inherent dangerousness of firearms. ${ }^{252}$ Indeed, "[c]ommon sense tells us that

249. Broughton, supra note 237, at 389.

250. Robinson, 846 F.3d at 707 (Harris, J., dissenting) ("I cannot endorse a rule that puts us on a collision course with rights to gun possession rooted in the Second Amendment and conferred by state legislatures.").

251. See supra note 237 and accompanying text.

252. See, e.g., City of Cincinnati, The Cincinnati Police Department Procedure MANUAL $\$ 12.550 \quad \mathrm{https} / /$ www.cincinnati-oh.gov/police/department-references/policedepartment-procedure-manual/ [https://perma.cc/UD6D-SVBP] ("The authority to carry and use firearms in the course of public service carries with it the highest level of responsibility."); N.J. Div. of Criminal Justice Police Training Comm'n, Basic Course Firearms Manual 8, 15 (2009), http://www.state.nj.us/lps/dcj/njptc/manuals/BasicCourseFirearmsManual.pdf [https://perma.cc/QK39-JN6B] (requiring that "relevant safety shall be maintained by keeping all firearms' muzzles pointed towards the ground" and requiring all trainees to "describe the ... lethal capabilities of the agency handgun(s) and shotgun(s)"); MiChaEL DOUGLAS JACKSON, OR. 
guns are inherently dangerous; responsible gun owners treat them with great care." ${ }^{253}$ Unlike baseball bats, broken bottles, and even knives and swords, firearms exist for one reason only: to inflict lethal damage to a target. They create an explosion to thrust a metal projectile at incredibly high velocities to pierce and destroy objects. They have the capacity to inflict a wider range of damage to a greater number of targets in a shorter amount of time than any other weapon, including the most dangerous knives and swords.

Perhaps most importantly in this context, well over half of the 257 Arizona police officers who have been killed in the line of duty were killed by gunfire. ${ }^{254}$ One hundred forty-six Arizona officers have been killed in the line of duty by a firearm; the next closest type of death (automobile crash) claimed only twenty-five lives. ${ }^{255}$ Exactly four Arizona officers have lost their lives on duty from stab wounds. ${ }^{256}$

For these reasons, a modified categorical approach authorizing automatic frisks of firearms carriers only appears to best balance the rights of armed Arizonans with the needs and safety of officers and the surrounding community. On the one hand, armed Arizonans can freely carry concealed firearms in public without fear of unnecessary scrutiny by law enforcement, unless they engage in suspicious behavior independent of firearms possession sufficient to warrant an involuntarily detention. But once that detention occurs, the presumption of law abidingness disappears, and the balance of protection shifts to the officer and the immediately surrounding public to neutralize any possible threat posed by a firearm in the hands of a lawfully stopped suspect.

Such a "firearms exception" to Fourth Amendment search law necessarily means that knives, no matter how dangerous, would be subject to an independent dangerousness inquiry. One might find this approach strange, given the destructive potential of exotic blades like swords and the fact that federal sentencing guidelines include "knives" in the definition of inherently dangerous instrumentalities. But the simple reality is that knives do not carry the immediate destructive power of firearms, nor do they have the range of potential lethality that handguns and semi-automatic weapons carry.

Dep't of Pub. Safety Standards and Training, Police Officer Field Training Manual 22, 28 (2013), https://www.ci.medford.or.us/files/Police\%20Field\%20Training\%20Manual\%20614-2013.pdf [https://perma.cc/Y4CP-F3GY].

253. Ezell v. City of Chicago, 651 F.3d 684, 714 (7th Cir. 2011).

254. Arizona Line of Duty Deaths, OfFICER Down Memorial, http://www.odmp.org/search/browse/AZ [https://perma.cc/4LF6-LT78] (last visited Mar. 17, 2019).

255. Id.

256. Id. 
Therefore, while recognizing the inherent dangerousness of the firearm and its destructive power may counsel in favor of an automatic frisk, the same argument does not necessarily extend to knives.

Another way to conceptualize this "independent dangerousness" inquiry approach is as a common tort law risk assessment. The Fourth Amendment, as interpreted by Terry and its progeny, require officers to make a fact-based determination about a suspect's potential dangerousness. ${ }^{257}$ This inexact science, conducted in a short timeframe under often tense conditions, essentially requires officers to assess the amount of risk a suspect poses and determine whether that risk requires the precaution of a search ${ }^{258}$ Put another way, does the probability of harm $(P)$ caused by the armed suspect combined with the potential magnitude of that harm $(L)$ justify the taking of the precaution $(B)$ of a protective frisk? ? $^{259}$

As with all officer-suspect encounters, the inputs in each circumstance will be highly fact- and context-specific. But in a lawfully, heavily armed state like Arizona, the default probability that an armed Arizonan will harm a police officer should be low. Of course, that probability may increase for lawfully stopped individuals suspected of criminal behavior, and may increase dramatically if the individual is suspected of a violent crime as compared to a minor traffic violation.

The input that will change most significantly based solely on the type of "weapon" at issue is the magnitude of harm variable. Even if two Arizonans are lawfully stopped on the same street on suspicion of jaywalking and pose equally low danger profiles, the one armed with a handgun inherently poses a far greater and more immediate danger to the officer and the surrounding public than does the one armed with a switchblade. Thus, this risk assessment approach to Terry frisks further confirms the reasonableness of a modified categorical approach for firearms and an individualized assessment approach for all other weapons, including knives.

257. See Terry v. Ohio, 392 U.S. 1, 21-22, 28 (1968).

258. See Braswell v. McCamman, 256 F. Supp. 3d 719, 724 (W.D. Mich. 2017) ("[Police] [o]fficers who put themselves in danger to keep our communities safe "are often forced to make split-second judgments - in circumstances that are tense, uncertain, and rapidly evolving." (quoting Graham v. Connor, 490 U.S. 386, 396-97 (1989))).

259. See United States v. Carroll Towing Co., 159 F.2d 169, 173 (2d Cir. 1947) ("[I]f the probability [of an accident] be called $P$; the injury, $L$; and the burden [of adequate precautions] $B$; liability depends upon whether $B$ is less than $L$ multiplied by $P$ : i.e., whether $B[<] P L$."); see also Stephen G. Gilles, On Determining Negligence: Hand Formula Balancing, the Reasonable Person Standard, and the Jury, 54 VAND. L. REv. 813, 816-25 (2001) (discussing the contours and limits of the Hand Formula and related risk-assessment metrics). 


\section{CONCLUSION}

Like much of the country, Arizona has chosen to significantly expand gun and other weapon possession rights in the public square. Not surprisingly, the number of Arizonans carrying weapons in public has significantly increased as a result. Whether this widespread open and concealed carry of weapons makes Arizonans safer is a matter of significant empirical debate. Whether public carry of firearms is protected by the Arizona Constitution or United States Constitution remains an unresolved legal issue. But it is indisputable that the arming of Arizona has complicated the job of Arizona's law enforcement and fundamentally changed the legal standards governing police authority to conduct a stop and frisk.

The foregoing discussion highlights the need for Arizona's police officers to recognize that public possession of a firearm or other weapon, standing alone, no longer satisfies the Fourth Amendment's "reasonable suspicion" standard. The legalization of public carry has eliminated any viable argument that weapons possession by itself implicates criminal activity. Moreover, as the Arizona Supreme Court correctly concluded in State v. Serna, the absence of such suspicion precludes the lawful frisking or disarming of an individual carrying weapons in public purely out of concern for public safety. This increased zone of protection for armed Arizonans from involuntary police interaction changes over half a century of "stop and frisk" practice and jurisprudence and requires a recalculation of risk assessment and reasonable suspicion.

But this zone of protection fades once an armed Arizonan reasonably falls under suspicion of criminal activity. At that point, no presumption of law abidingness remains and officers can and should take all necessary precautions to protect themselves and the surrounding public. In the case of firearms possession, risk assessment principles require an automatic frisk and disarmament when doing so is practicable and enhances safety. For other weapons, including bladed weapons uniquely protected in Arizona, officers should carefully assess the utility of conducting a frisk in light of Terry's narrow original goal of officer and public protection. This careful balancing of Terry's two-pronged test-greater protections for armed Arizonans from investigatory seizures but fewer protections from protective searches-both accords with existing Fourth Amendment principles and balances the expanding rights of armed civilians with the needs of officers protecting those same civilians. 